\title{
CIUDADES Y HERMANDADES EN LA CORONA DE CASTILLA. APROXIMACIÓN SOCIOPOLÍTICA
}

\author{
MARÍA ASENJO GONZÁLEZ \\ Universidad Complutense de Madrid
}

\begin{abstract}
SUMARIO
Introducción.- 1. El poder político en el concejo: los fueros.- 2. Innovaciones sociales y cambios políticos en el reinado de Alfonso X.- 3 . Reacciones sociales. Las primeras hermandades: A) Las primeras hermandades concejiles. B) La hermandad bilateral. C) La hermandad acordada. D) Las hermandades políticas.- 4. La hermandad de 1282. El papel de la nobleza.- 5. Las hermandades desde 1295. Tipos y contenidos: A) La hermandad de 1295 y las hermandades locales.- 6. Las hermandades durante el reinado de Fernando IV y su prolongación en las Cortes: A) Las Cortes de 1312.- 7. La hermandad de 1312. La nobleza.- 8. El fin de las hermandades. Instituciones y símbolos de la Hermandad.- Conclusion.
\end{abstract}

\section{INTRODUCCIÓN}

La participación de las ciudades castellanas en la política del reino a través de las organizaciones que conocemos como hermandades constituye uno de los aspectos históricos de mayor atractivo. Desde el punto de vista del desarrollo historiográfico, en los últimos decenios se ha producido una relevante aportación al estudio de las hermandades en la Corona de Castilla, que ha proporcionado la ocasión de conocer con profundidad un fenómeno político que se documenta desde el siglo XII, despega con fuerza en el siglo

"Anuario de Estudios Medievales". 27 (1997) 
XIII $^{1}$ y tras perder su protagonismo político desde 1325 , se mantuvieron como formas de asociación de concejos para fines diversos hasta el siglo $\mathrm{XVIII}^{2}$. Conviene recordar que a fines del siglo XV las hermandades en Castilla vuelven a colocarse en primera línea de actividad política que conecta con el estallido de las Comunidades ${ }^{3}$.

Recordemos que el término hermandad tiene un significado propio de fraternidad y de asociación que ayuda a entender de inmediato lo que el vocablo sugiere. También se define como asociación de marcado carácter horizontal en la que se podrían incluir gentes diversas, unidas por unos mismo propósitos ${ }^{4}$. Las hermandades del período medieval se agrupan en solidaridades vecinales, asociaciones concejiles y federaciones políticas. En los tres casos el término hermandad define lo básico del concepto asociativo, pero cambia según los contenidos, la importancia y el número de los miembros que componen el grupo. Desde una perspectiva histórica se puede tratar de precisar en qué momento tuvo lugar la aparición de la Hermandad como una organización para fines políticos, que se retrotraería hasta 1110 o incluso a fechas anteriores, si bien en estos casos eran sobre todo ligas políticas, realizadas en el marco local, y no verdaderas confederaciones 5 . Entre 1282 y 1325 se habían desarrollado plenamente unas hermandades con dimensión política y capacidad para querer intervenir en los asuntos de reino, al tiempo que otros tipos de hermandades, constituidas con fines

'En una reciente revisión del tema se da una completa y actualizada bibliografía. Ver: César GonzÁlez Mínguez, Aproximación al estudio del "movimiento hermandino" en Castilla y León, "Medievalismo", I-II, (1991-1992), pp. 34-55 y 29-60, también en el trabajo de Luis Miguel DíEz DE Salazar, Ordenanzas de la Hermandad de Guipuzcoa de 1379, "Acta historica et archaeologica medievalia”, 7-8, (1986-87), pp 245-6. Ver también la interesante valoración de Manuel GARCía FERnÁNDEZ. La Hermandad General de Andalucía durante la minoría de Alfonso XI de Castilla: 1312-1325, "Historia. Instituciones. Documentos", 12 (1985), pp. 351-353, notas 1 y 2.

${ }^{2}$ Ese fue el caso de la Hermandad vieja de Toledo, Talavera y Villarreal. Ver Augusto PAZ Y Mélia, La Santa Hermandad Vieja y la Nueva Hermandad general del Reino, "Revista de Archivos Bibliotecas y Museos", I (1897), pp. 97-104.

${ }^{3}$ Yolanda GuerRero NAVARRETE, y Jose María SÁNCHEZ BENITO, El proceso constituyente de la Hermandad General. Los ordenamientos de 1476 a 1478, "Anuario de Historia del Derecho Español", 1 (1989), pp. 633-698. Jose María SÁNCHEZ BENITO, Notas sobre la Junta General de la Hermandad en tiempos de los Reyes Católicos, "Anales de la Universidad de Alicante: Historia Medieval", 8 (1992), pp. 147-168.

${ }^{4}$ Yves DuRand, Les solidarités dans les sociétés humaines. París, 1987.

${ }^{5}$ Así lo entiende Julio PuYOL, Las Hermandades de Castilla y León, Madrid, 1913, p. 11. Este autor cree, a partir del fuero de Salamanca, que las Hermandades fueron ya conocidas en el último tercio del siglo XI, p. 19. 
económicos o ganaderos, actuaban también desde el siglo XIII y se prolongaron en algunos casos hasta la Edad Moderna.

En el presente trabajo nos proponemos repasar el origen y desarrollo de las Hermandades en la Corona de Castilla en el período de 1282-1325 y con las ciudades en el punto de mira de nuestro interés. Saber que les movió a entrar en el movimiento de las hermandades, cual fue su papel y por qué acabó fracasando todo ese esfuerzo, constituye el objetivo del mismo. Para ello, contamos inicialmente con los importantes y completos estudios realizados en los últimos años, a partir de los que se ha llegado a conclusiones válidas acerca del desarrollo histórico de las Hermandades y de sus implicaciones en la política de reino'.

Recordemos que desde una perspectiva historiográfica el interés por el estudio de las hermandades se remonta al siglo pasado, ya que, según Julio Puyol, fue Martínez Marina el primero en recuperar el significado histórico de este movimiento que se iniciaba en 1282. Según su interpretación, las causas que influyeron en la aparición de estas confederaciones fueron: el despotismo de los reyes y las turbulencias políticas que amenazaban al reino ${ }^{7}$. A esa teoría respondieron otros autores, llamando la atención acerca de la importancia de los asuntos de seguridad pública en las hermandades, lo que les llevó a pensar que habían sido creadas por los pueblos para mantener el orden, contener las ambiciones de la nobleza y apoyar a la monarquía ${ }^{8}$. Ciertamente se dibuja un panorama triángular, marcado por Hermandades, nobleza y monarquía que ha sido punto de encuentro de numerosos estudios ${ }^{9}$. Los historiadores del Derecho destacaron preferentemente el carácter asociativo e institucional de las Hermandades ${ }^{10}$. Por último, desde una perspectiva más social y económica se ha reivindicado

\footnotetext{
${ }^{6}$ Los trabajos de Luis SuÁREz FERnÁNDEZ, Evolución histórica de las hermandades castellanas, "Cuadernos de Historia de España", XVI (1951), pp. 5-78, César GonZÁlez Mínguez, Aproximación al estudio, cit. y Antonio ÁlvarEz DE MORALES, Las Hermandades, expresión del movimiento comunitario en España, Valladolid, 1974.

${ }^{7}$ Teoría de las Cortes, II, Madrid, 1813, p. 469. Ver Julio PuYOL, Las Hermandades, nota 1.p. 10

${ }^{8}$ El breve estudio de Luis Montalvo y Jardín, Las Hermandades de Castilla. Juicio de esta institución, Madrid, 1862. esbozaba estas interpretaciones y mantenía que la primera fue la creada en Sahagún en 1110, pp. 9-10.

${ }^{9}$ Luis SUÁREz FERnÁndez, Evolución histórica de las hermandades, cit, pp. 5-15. Este importante trabajo que se ha convertido en un clásico debate algunos de los puntos de vista sobre el asunto mencionado.

${ }^{10}$ Antonio Álvarez de Morales, Las Hermandades, cit. pp. 9-11.
} 
el movimiento como lucha antiseñorial que trató de frenar los abusos de los malhechores feudales" ${ }^{11}$. Sobre un tema tan sugestivo todavía faltan estudios globalizadores que sean capaces de incorporar nuevas perspectivas de análisis y nos permitan entender mejor un período histórico tan rico y complejo como fue el siglo XIII' ${ }^{12}$.

En un trabajo reciente se retoma el análisis de las Hermandades sobre una perspectiva más social y económica para resaltar que las Hermandades surgieron con el objetivo de defender los fueros y privilegios particulares de cada ciudad y de cada concejo, amenazados por la tendencia a la unificación del sistema jurídico y político ${ }^{13}$. Una interesante aportación de este trabajo es la crítica a la teoría de la supuesta debilidad monárquica como origen de las hermandades, que no explicaría el proceso, y apunta que serían las nuevas tendencias de unificación jurídica y centralización política del reinado de Alfonso $X$ las claves de una explicación más sólida ${ }^{14}$. La segunda aportación relevante es que destaca la relación entre supresión de la hermandad en 1325 y la aparición del regimiento, como forma estable de organización de un gobierno oligárquico en las ciudades castellanas, a partir de 1345. En tercer lugar analiza la carga antinobiliaria de las Hermandades, asunto en el que destaca las contradicciones de la oligarquía urbana ${ }^{15}$.

Desde esta óptica, entendemos que se puede avanzar para ofrecer una mejor comprensión de este fenómeno desde una perspectiva de análisis más próxima a la dinámica local y a los aspectos sociales, referentes que resultan fundamentales en el desarrollo del presente trabajo sobre las hermandades. Así, trataremos de conocer las razones que movieron a los concejos de la Corona de Castilla a participar en las Hermandades y a constituirse en una fuerza política con un programa reivindicativo, en un período de graves

\footnotetext{
"Salustiano Moreta Velayos. Malhechores feudales. Antagonismos y alianzas de clases en Castilla, siglos XIII-XIV. Madrid. 1978. pp. 179 y ss.

'César González Minguez. Aproximación al estudio, ob. cit., p. 43. En este trabajo se propone abordar el estudio de las Hermandades desde la perspectiva de las relaciones de poder y haciendo suya la idea de "colocar a los concejos como bloque de poder en el sistema de parcialización del poder feudal propio de la formación política castellano-leonesa", p. 36.

1:José María Mínguez Fernández, Las Hermandades generales de los concejos en la Corona de Castilla. Objetivos, estructura interna y contradicciones en sus manifestaciones iniciales). "Concejos y ciudades en la Edad Media Hispánica. II Congreso de Estudios Medievales". Fundación Sánchez Albornoz. León. 1990, pp. 539-567.

"Ibidem, p. 551-2.

${ }^{15}$ Ibidem, p. 556 y $560-5$.
} 
tensiones políticas. Nuestro propósito es situarnos en la perspectiva de los intereses concejiles y conocer los atractivos que las diferentes oportunidades presentaban a las facciones urbanas que se oponían en el seno de las ciudades. Nos ocuparemos de las hermandades generales y para ello será preciso retroceder en el tiempo y conocer la situación que se vivía en el seno de la sociedad concejil desde mediados del siglo XIII, y las innovaciones que conoció durante el reinado de Alfonso X (1252-1284).

Para algunos autores el origen de las hermandades se localizaría en la Extremadura castellana ${ }^{16}$. Ciertamente los concejos de la llamada Extremadura representaban un conjunto relativamente homogéneo en cuanto a su construcción social y económica se refiere. La organización concejil se había mostrado particularmente eficaz para dominar un extenso territorio a partir de un núcleo fortificado en el que se ubicaba la villa, y en ellas los habitantes del concejo se reconocían como miembros de alguna de las collaciones que se distribuían indistintamente por la ciudad o la villa y por su Tierra ${ }^{17}$. La fuerte cohesión social que exigía el hábitat en el seno de las collaciones se lograba básicamente a partir de los vínculos familiares. A ellos se fueron añadiendo en el curso de los siglos XII y XIII nuevas formas de integración asociadas a los valores y vínculos feudales. Lo cierto es que a mediados del siglo XIII en los concejos de la Extremadura convivían dos grupos jerárquicos que compartían responsabilidades y funciones en un ambiente de franca rivalidad. Destaquemos en primer lugar a los miembros de las jerarquías familiares, que eran elementos diferenciados dentro del grupo, y cuya capacidad y méritos le hacían merecedores de la condición de jefes. Se reconocían en formas de organización familiar afines al sistema cognaticio de parentesco, que no se veían condicionadas a la elección de su jefe por criterios de predominio de varón o de filiación, sino que la jerarquía gozaba de una mayor movilidad y permitía la selección del más capaz según las circunstancias. Hay que pensar que a estos principios se añadirían muy pronto otros referentes de riqueza, poder y prestigio en los que la influencia

\footnotetext{
${ }^{16}$ César González Mínguez, Aproximación al estudio, ob. cit., p. 45, nota 51-52.

${ }^{17}$ María AsEnjo González. Ponvoirs et organisation sociale dans une région de colonisation: L'exemple de Soria. "Les villes frontière. Moyen Âge-Époque Moderne" Coord. Denis Menjot, París. 1996. pp. 17-40 y Espacion yociedad en la Soria Medieval (siglos XIII$X V I)$. Soria (En prensa), Cap. I.
} 
de los valores feudales se fueron haciendo patentes ${ }^{18}$. Estas jerarquías se denominan en la documentación señiores y también hombres buenos ${ }^{19}$.

El otro grupo jerárquico de los concejos de las Extremadura lo constituían los caballeros villanos, un sector social emergente que se había favorecido de las guerras de frontera y cuyo patrimonio había crecido notablemente gracias a las capturas de botín. Este conjunto social se asimilaba mejor a las estructuras agnaticias de organización familiar que iban asociadas al linaje y la estructura feudal del poder ${ }^{20}$.

La rivalidad entre estos dos grupos jerárquicos sembró el reino de conflictos y tensiones en particular durante el siglo XIII y en ocasiones la monarquía tuvo que mediar para evitar rupturas irrevocables que ponían en peligro la unidad de algunos territorios de realengo ${ }^{21}$. Un episodio conocido que se puede relacionar con la tensión entre caballeros y hombres buenos es el relatado en la "Crónica de la Población de Avila", que refiere acontecimientos que todavía estaban presentes en la memoria de las gentes del siglo XIII y que en el fondo quieren justificar la preponderancia del conjunto de los caballeros que se agrupa en la facción de los serranos enfrentados a otro sector al que se denomina la otra gente, en el que suponemos se reunía parte de la población del concejo bajo las jerarquías naturales ${ }^{22}$. En este caso la razón del conflicto había sido el reparto del botín, que los caballeros habían logrado en sus acciones castigo ${ }^{23}$. En el curso del siglo XIII se puede afirmar que en estas diferencias los caballeros buscaban el apoyo de los

\footnotetext{
${ }^{18}$ María ASEnjo González. Parentesco y sociedad en el origen de la nobleza urbana en Castilla. Siglos XII y XIII. "Villes et Sociétés urbaines au Moyen Âge". París, 1994. p. 143.

${ }^{1 "}$ El Fuero de Soria denomina señiores a las jerarquías del concejo que no son los caballeros, aunque la forma más general de reconocerlos en la documentación es por el apelativo de hombres buenos.

20María Asenjo González, Parentesco y sociedad, cit., p. 144.

${ }^{21}$ Ese el caso de las tensiones que surgieron entre hombres buenos y caballeros de Segovia quye llevaron al desmembramiento de algunos lugares de la Tierra, que fueron restituidos tras la mediación de Fernando III. quien puso paz entre los enfrentados y resolviendo el conflicto a favor de los caballeros. Ver: María ASENJO GONZÁLEZ. Sociedad y economía en las relaciones ciudady Tierra en Segovia durante la Edad Media. "Segovia 1088-1988. Congreso de Historia de la ciudad". Segovia, 1990, pp.64-67. Un conflicto similar encontramos en Arévalo, ver: Julio GONZÁlez, Reinado y diplomas de Fernando III. Madrid, 1960, II, doc. 55, pp. 67-68.

"Amparo Hernández Segura (Edt.) Crónica de la población de Ávila, Valencia, 1966. pp. 14-19

${ }^{23}$ María ASEnjo GonzÁlez, La repoblación de las Extremaduras (siglos X-XIII). "Actas del Coloquio de la V Asamblea General de la Sociedad Española de Estudios Medievales", Zaragoza, 1991, pp. 94-95.
} 
monarcas que les ratificaban sus privilegios, mientras las jerarquías naturales se amparaban generalmente en los fueros.

\section{EL PODER POLÍTICO EN EL CONCEJO: LOS FUEROS}

Ciertamente los fueros y el derecho consuetudinario mantenían el referente de los usos antiguos en los que se reconocía la primacía de las jerarquías naturales, que en el seno de la comunidad representaban al poder, y respecto a su persona se establecían una serie de disposiciones, cuyo estudio desvela hasta que punto se les consideraba un paradigma de poder político. En este sentido, el fuero extenso de Soria, otorgado por Alfonso X, incluye algunas disposiciones sobre las limitaciones y alcance de la venganza que refleja la base del entramado político sobre el que funcionaba la sociedad concejil, que define la condición del traidor como la del peor de los criminales y a él se le aplican las penas más duras ${ }^{24}$. Curiosamente, era traidor todo aquel que atentase contra la persona del señor natural y de su hijo, lo mismo que también lo sería el que atentase contra su padre o su madre o contra otros miembros de la parentela. Por último, sería traidor el que rompiese una tregua. Esta descripción reducía a un marco social y político próximo todo el entramado de poderes inmediatos, con presencia en el ámbito concejil, que eran los que valoraba el fuero para dar la definición de traidor, descartando otras posibilidades de traición a altas jerarquías y poderes como la Iglesia o la monarquía, o a sus representantes o delegados, a quienes no se integraba como propios. Recordemos que en el esquema de los grupos gentilicios el traidor es el asesino por antonomasia, el que reunía todos los deseos de venganza de la comunidad, y por lo tanto se convierte en un prototipo de lo malo. Resulta interesante valorar la gradación jerárquica que muestra el fuero en la apreciación del delito de traición ya

\footnotetext{
${ }^{24}$ Galo SÁNCHEZ, Fueros castellanos de Soria y Alcalá de Henares, Madrid, 1919, cap. 491, p. 189: "Todo omne que matare a otro a tryçion o a aleff, ssea rrastrado e enfforcado por ello, e tomen de sus bienes las calonnas dobladas; e si sus bienes non cumpleiren, pierda lo que oviere; e las casas del traydor ssean derrocadas" ( $f^{\circ} 82 \mathrm{v} /$ ).

El fuero de Soria de mediados del siglo XIII resulta de gran interés para conocer diferentes aspectos de la vida social y política de los concejos de la Extremadura. Ver nuestro trabajo: Espacio y sociedad, cit., parte 3,I.
} 
que destaca en primer lugar al que atentase contra el señor ${ }^{25}$, a continuación al que lo hiciera contra sus familiares y parientes de descendencia directa, y finalmente al que rompiese una tregua para matar. Esa prelación refleja la jerarquía establecida en el seno del concejo, donde se destacaba claramente la figura jerárquica del señor natural, a quien se situaba por encima del resto de los miembros de la parentela. Cualquier ofensa hecha al señor sería duramente castigada, mientras que en caso de atentar contra sus familiares sólo se castigaría en caso de muerte. En resumen, un marco de poderes inmediatos que, a modo de sociedad política, permitía unas gradaciones de poder y en el que destacaba siempre la figura del señor.

Las especificaciones del delito que comete el traidor que ataca a su señor son significativas de que el legislador pensaba en un peligro concreto que atentase contra la solidez de mando del señor, en tanto que jerarquía, y todo indica que sólo se vería seriamente afectado si fuese uno de sus parientes el que se enfrentara a él ${ }^{26}$. Además, el texto se presta a confusión porque utiliza el término rregnar para referirse al gobierno y ejercicio de su poder y aunque en el mismo texto menciona a la figura del rey no ofrece dudas acerca del mensaje que encierra, ya que indica en qué ocasiones es traidor alguien que atentase contra su señor o su hijo. No obstante, se acepta que no fuese considerado traidor aquel que atentara contra el hijo de su sennor, siempre que fuese cuando este hubiese salido del mandato de su padre, o mantuviese relaciones sexuales con la mujer de su señor, o aconsejase a otro que así lo hiciese. En último termino, tampoco sería traidor si atentara contra su señor cuando este hubiese sido desheredado por el rey, o traicionase el castillo o la villa murada ${ }^{27}$. Esa mención del hijo del señor en los delitos de traición nos indica que también los linajes de las parentelas se estaban viendo afectadas por la construcción agnaticia y que el hijo del señor gozaría de privilegios y reconocimiento por el hecho de ser de su

\footnotetext{
${ }^{25}$ Ibidem.,: cap 492, pp. 189-190: "Traydor es qui mata su sennor natural o lo prende o mete mano en el o lo manda o lo conseia ffazer...". Si muchos de los capítulos del fuero se redactaron bajo la influencia del fuero Real, los que definen quien es traidor corresponden al elenco de los derivados del derecho consuetudinario.

${ }^{26}$ Ibidem,: ". .o quier alguna destas cosas ffaze a fijo de su sennor natural que deve rregnar demientre que non salliere de mandato de su padre, o que yaze con mugier de su sennor o que es en consejo que yaga otro con ella, o que dehereda su rey o es en consejo de desheredarle, o que trahe castillo o villa murada".

${ }^{27}$ Ibídem, p. 190,"... o que deshereda su rey o es en conseio de desheredarle, o qui trahe castiello o villa murada".
} 
descendencia. Ahora bien, sus actitudes parecen limitadas a permanecer bajo el poder de su progenitor y a no mantener relaciones sexuales con su esposa, que indirectamente se convierte en un referente de transmisión y acceso al poder. Las ciudades de este período mantenían en su seno una sociedad política compleja y fuertemente jerarquizada, que se reconocía en grandes grupos integrados en el concejo a través de la estructura de las collaciones que formaban el concilium.

En la disposición del fuero de Soria, observamos que se sitúa a los vecinos entre dos dimensiones socio-políticas con influencia en el concejo, una sería la parentela con de los deberes de fidelidad para con el sennor que era su jerarquía natural, y otra era el rey que convertido, eso sí, en un poder de referencia, era quien en última instancia medía la legitimidad del propio poder del sennor. De ese modo, el rey dejaba de ser un poder lejano e imperceptible y adquiría su verdadera dimensión en tanto y cuanto servía para contener los abusos del señor y evitar que se convirtiese en tirano.

Esta teoría política de poderes que se legitiman entre sí y que al tiempo se vigilan, incluye a los miembros de las parentelas que si bien quedaban sujetos al poder del señor disponían de capacidad para sustituirle si degeneraba en tirano. Ya que, según lo expresado en el fuero, era tirano aquel señor que no cumplía sus obligaciones para con el rey o para con el concejo.

El fuero extenso de Soria nos ha mostrado la compleja trama sobre la que se organizaba el poder de las jerarquías de las parentelas, a las que denomina señiores y que podemos asimilar a los llamados hombres buenos de los concejos. Una estructura política de construcción jerarquica y de origen familiar que desde principios del siglo XII se sentía parte del concejo y mantenía como poder de referencia al rey.

En ese ambiente de gran cohesión social fueron emergiendo los caballeros-villanos, que constituyen el otro grupo de poder en el seno del concejo, y cuyo oficio de armas les permitía acceder a las ganancias del botín, al tiempo que se beneficiaban de los privilegios y exenciones que, por su servicio de armas, les otorgaba la monarquía. Pero no olvidemos que estos hombres a caballo procedían también de las parentelas y durante mucho tiempo se mantuvieron integrados y ligados a ellas, como miembros destacados de las mismas, porque gracias a su soporte podían adquirir el caballo y las armas con las que prestaban el servicio militar, al tiempo que también los necesitaban para mantener la seguridad del territorio y los bienes del concejo lo mismo que para ayudar al rey en sus acciones bélicas. Esa 
fuerte dependencia hizo lento el despegue de los caballeros-villanos y es lógico suponer que el ritmo de distanciamiento fuera diferente en los distintos concejos de la Extremadura. No hay duda acerca de la importancia que la riqueza tenía en ese proceso y en concreto en la zona de la Extremadura, donde el valor de los bienes muebles se acrecentaba si tenemos en cuenta que la ganadería era la actividad más destacada ${ }^{28}$.

Los monarcas apoyaron decididamente a los caballeros en sus reclamaciones y solicitudes con el deseo de afianzar a este grupo militar, mejor capacitado y dispuesto para asimilar las formas sociales y políticas asociadas al poder feudal. Privilegios, exenciones, fallos judiciales y otras componendas contribuyeron a que los caballeros villanos se situasen en algunos concejos a la altura de los señores de las parentelas u hombres buenos. Pero este sector emergente representaba otro mundo social que en algunos aspectos fundamentales no era compatible con la estructura de las parentelas, que se mantenía firmemente ligada a la estructura de las collaciones del concejo, y tampoco lo era con algunos de los principios del derecho consuetudinario preservado en los fueros.

\section{INNOVACIONES SOCIALES Y CAMBIOS POLÍTICOS EN EL REINADO DE ALFONSO X}

Si los reyes de Castilla y León habían apoyado a los caballeros villanos, ninguno había llegado tan lejos como lo hizo Alfonso X en 1264. El reinado de este monarca resulto excepcional para los concejos de Extremadura $^{29}$. En el contexto de una ambiciosa política fiscal ${ }^{30}$ y con el deseo de implicar a los caballeros villanos, en tanto que grupo oligárquico, en la política del reino, el rey Alfonso X emitió un privilegio en Sevilla el 29 de Abril de 1264, dirigido a favor a los concejos de Extremadura para

\footnotetext{
${ }^{28}$ Jose María Minguez, Ganadería, aristocracia y reconquista en la Edad Media castellana, "Hispania". 151 (1982), pp. 341-354.

"La magnífica figura de Alfonso X no deja de sorprendernos en sus múltiples facetas. Hoy contamos con una reciente y valiosa bibliografía sobre su persona y su reinado de ella destacaremos dos recientes monografías: Manuel GONZÁLEZ JIMÉNEZ, Alfonso X. Palencia, 1995 y Joseph F. O'Callaghan. El reinado de Alfonso X de Castilla. Sevilla. 1996.

"Maria ASENJo GONZÁLEz. Fiscalidad regia y sociedad en los concejos de la Extremadura castellano-oriental durante el reinado de Alfoniso $X$. "Homenaje al Profesor Juan Torres Fontes". Murcia 1987, pp. 69-84
} 
atender una súplica presentada por ellos a la reina doña Violante a fin de que intercediese ante su esposo y les aliviase los impuestos. En este documento los caballeros se presentaron como portavoces de los hombres buenos para tratar cuestiones fiscales sobre el cobro de los diezmos y las tercias reales ${ }^{3 !}$.

Salvo en estas cuestiones de fiscalidad, el resto del contenido del documento afectaba a los caballeros y a ellos les proponía reforzar la relación con el rey a partir de la ratificación del carácter feudovasallático de sus obligaciones militares para con el monarca. Para ello dispuso que se reconociera cierta condición privilegiada a los caballeros que fuesen armados por el rey o por su hijo heredero, los cuales recibirían el pago de quinientos sueldos y ocuparían preferentemente alcaldías y otros oficios de justicia, además de poder hacer excusados entre sus servidores, parientes y allegados $^{32}$. Esos caballeros armados por el rey mantendrían los privilegios concedidos con "anterioridad y en caso de fallecimiento su viuda podía conservar la asignación mientras no volviese a casarse, de ese modo se otorgaba el soporte de una renta anual y los privilegios asociados, que contribuirían a que los caballeros villanos fuesen creando sus propias familias a modo de linajes. Ahora bien, la medida podría llegar a ser un asunto de conflicto con la alta nobleza ya que establecía que estas condiciones no sólo se ofrecerían a los caballeros que fuesen armados por primera vez, sino que se brindaban también a los caballeros que estuviesen al servicio de infantes o de ricos hombres y que quisiesen servir al rey. En tales casos, se aseguraba que recibirían cartas de concesión del monarca como si se tratase de sus vasallos y mandaría que se les pagasen los quinientos sueldos acordados. Pero los caballeros villanos de los concejos que no quisiesen ser vasallos del rey podrían permanecer con los infantes y ricos hombres, eso sí ni percibirían los quinientos sueldos, ni obtendrían los privilegios otorgados en este diploma ${ }^{33}$. Atendiendo a la condición

\footnotetext{
${ }^{3}$ El documento fue transcrito por Antonio UBIETO ARTETA. Colección Diplomática de Cuéllar. Segovia, 1961, doc. 21. pp. 60-66. Fue estudiado por Aquilino IGLESIAS Zamora, El privilegio general concedido a las Extremaduras en 1264 por Alfonso X. Edicion del ejemplar enviado a Peñafiel el 15 de Abril de 1264. "Anuario de Historia del Derecho Español" (en adelante AHDE), 53 (1983), pp. 546-521

3'María ASEnjo GonzÁlez. Fiscalidad regia ý sociedad, cit. p.76, nota 33.

3:Antonio Ubieto ARTETA, Colección Diplomática, ob. cit., p. 64: "Otrossi por fazerles mayor merçed otorgamos que los cavalleros que fueron fechos fata el dia del era deste privilegio, de los infantes e de los ricos omnes que quisieran venir a nos, e que nos dieremos
} 
militar de los caballeros, en el documento se trataban también asuntos referidos a la defensa y buen estado de las fortificaciones urbanas, para las que disponía derivar el monto de las caloñas (multas) que se tomaban por la defensa de los términos.

Las concesiones eran importantes ya que se ofrecía cierta inmunidad a los caballeros en caso de verse acusados de cometer delitos de gravedad, por los que tuviesen que ser juzgados y mereciesen ser castigados con pena de muerte o de exilio, en tales circunstancias obtendrían la protección y mediación regia, siempre que no hubiesen matado mientras se estuviese bajo tregua o a salvo, o participasen en actos de traición. En tales casos mandaba que se informase al rey para que él dispusiese lo más apropiado ${ }^{34}$.

Los privilegios se ampliaban al conceder a estos caballeros la posibilidad de tener mayordomos entre sus excusados y de que pudieran recibir de sus apaniaguados (exentos), el monto de las caloñas que antes percibían los alcaldes ${ }^{35}$. Por último, les otorgaba el libro del Fuero, que no sería otro sino el Espéculo ${ }^{36}$, y se comprometía a abrir una vía de comunicación directa con los caballeros bajo el compromiso de que la reina les atendería en caso de no poder hacerlo el rey ${ }^{37}$.

El documento resulta muy significativo de la situación vivida en el seno de los concejos y de la necesidad que los caballeros villanos tenían de contar con el apoyo del rey y de sus privilegios para romper ataduras con las jerarquías de sus parentelas y así poder imponerse sin conflictos como grupo oligárquico. A su vez, la monarquía precisaba del apoyo militar de los valerosos caballeros de la Extremadura a los que era preciso equipar militarmente a fin de que pudiesen prestar su servicio de armas en las campañas de Andalucía. Alfonso X buscaba mejorar las condiciones de los caballeros para la guerra pero introducía cambios importantes que desequili-

nuestras cartas de otorgamiento como los nuestros vasallos, que ayan aquesta onrra de los quinientos sueldos, e todas estas franquezas e las que han por nuestro privilegio".

"María ASENJo GonZÁlez. Fiscalidad regia y sociedad, cit. p. 77, nota 35.

"Ibiclem, notas 36 y 37.

"El Expéculo es un código que consta de cinco libros, redactado probalemente entre 1255 1260 y que era aplicado por los jueces de la corte. Ver: Francisco TOMÁs Y ValientE. Mamual de Historia del Derecho español. Madrid, 1995. pp. 235. Alfonso Garcia Gallo asegura que la expresión Fuero del Libro o Libro del Fuero se refiere al Espéculo.

${ }^{37}$ Antonio Ubieto ArTeta, Colección Diplomática, cit., p. 65: "E por fazerles mas bien e mas merçed, otorgandoles los nuestros privilegios e el libro del fuero que les diemos" 
braban la relación de fuerzas existente en el seno de los concejos ${ }^{38}$. Eso a la larga provocaría conflictos.

Este documento de 1264 se vale de un vocabulario feudovasallático que resulta estar en perfecta consonancia con el propósito político de Alfonso $\mathrm{X}$. El rey buscaba una mayor vinculación a partir de principios del contrato feudal y en este caso buscaba establecer un vínculo de vasallaje que equivaldría a un homenaje ligio de los caballeros hacia su persona. Otro asunto de gran interés para Alfonso $\mathrm{X}$ era difundir e implantar su obra legislativa, base teórica del poder de la monarquía feudal, y para ello no dudó en incluir a este selecto grupo de caballeros villanos, armados por el rey, entre sus beneficiarios. En suma, decisiones políticas que respondían a un plan organizado, en el cual el rey contemplaba a los concejos de realengo como base territorial y financiera al servicio de la monarquía. De esa forma el realengo no sólo sería un marco jurisdiccional y político, sino que pasaría a ser una referencia territorial sobre la que se iba a proyectar una política fiscal y socio-militar al servicio de la monarquía. Las diferencias sociales y políticas que existían en el seno de los concejos de la Extremadura habían inclinado al rey a apoyar a los caballeros, en tanto que grupo socio-militar más afín a sus proyectos de cambio político ${ }^{39}$.

El privilegio de 1264 no se llegó a cumplir con la continuidad que hubiese sido precisa para obtener los beneficios que las partes esperaban, y pasó a ser otra de tantas vías frustradas de la propuesta política del rey Sabio. Las razones que explican este fracaso se asocian necesariamente a las revueltas de las hermandades y a la oposición que estas medidas encontraron tanto en el seno de los concejos como entre los nobles laicos y eclesiásti$\cos ^{40}$.

Si el protagonismo de los caballeros villanos y su pujanza eran claros para la monarquía a mediados del siglo XIII, hasta el punto de hacer una propuesta como la de 1264, la monarquía también conocía el alcance del poder de las jerarquías naturales en el seno de los concejos. En un interesante texto de las Partidas, el rey Alfonso X hace una descripción del poder regio y busca referentes comprensibles y fiables sobre los que apoyar

\footnotetext{
${ }^{3}$ Joseph F. O'Callaghan, El reinado de Alfonso X, cit., p. 130. Este autor da casi por seguro que el privilegio se puso en vigor y se cumplió como estaba previsto.

${ }^{39}$ Manuel González Jiménez, Alfonsoso $X$, cit.. pp. 250-251.

${ }^{40}$ Maria Asenjo González. Fiscalidad regia y sociedad. cit. p.81.
} 
sus argumentaciones. El rey se define como vicario de Dios, cabeza del reino y vida del pueblo y, tomando como referencia una imagen antropomorfa, se presenta como alma y corazón del pueblot1. Así, lo mismo que los miembros del cuerpo defienden a estos, el pueblo debe guardar y defender al rey porque es su Señor natural ${ }^{42}$. Aquí parece que encuentra un lugar común sobre el que reflexionar acerca de la figura del rey y cuya capacidad de convicción resulta más eficaz para el lector. En ese esfuerzo la referencia antropomorfa y la alusión a la figura del señor natural parecen dos asideros seguros. Aunque la palabra señor tiene connotaciones feudales, Alfonso $\mathrm{X}$ distinguía entre la relación feudal que une a un señor y a sus vasallos y el vínculo entre el rey como señor natural y los naturales del reino, y en este sentido, señorío hace referencia a los dominios del rey y a su autoridad sobre su pueblo ${ }^{43}$.

De un modo preciso se establece en el texto de las Partidas un parangón entre el rey y los señores, entendidos estos como jerarquías naturales, con objeto de lograr un efecto de asimilación hacia una figura que todos conocían en mayor o menor medida y establecer con ella una semejanza profunda. Resulta interesante que en este tratado teórico que fueron las Partidas, Alfonso $\mathrm{X}$ quisiera describir ante el pueblo las prerrogativas del poder regio, buscando una comparación con las jerarquías naturales, a las que probablemente consideraba más arraigadas en su afirmación de poder en el marco local. Las obligaciones del pueblo para con su rey se reducirían a asegurar y garantizar su integridad física y moral. Las violaciones de esa obligación recibirían tratamiento de delito de traición, y como tales serían castigadas, en una equivalencia parecida a la que destacaba el fuero de Soria ${ }^{+4}$. En este caso resulta interesante tener en cuenta la

\footnotetext{
${ }^{4}$ Los códigos españoles concordados y anotados. Siete partidas, II. Partida $2^{\mathrm{a}}$. Tit. XIII, ley XXVI. pp. 405-406. Asegura que el quitase la vida al rey "quitaria a Dios su vicario, e al Reyno su cabeza, e al Pueblo su vida".

t'Ibictem, p. 405: "E bien assi como todos los miembros del cuerpo guardan e defienden a estos dos (el alma y el corazón), otros el Pueblo es tenudo de guardar, e de defender al Rey. que es puesto a semejanza dellos: e demas, que es Señor natural. Ca maguer los señores so de muchas maneras el que viene por naturaleza, es sobre todos, para auer los omes mayores debdos de lo guardar".

4:Joseph F. O Callaghan, El reinado de Alfonso X, cit. p. 41.

${ }^{4}$ Véase nota 19. Los códigos españoles concordados, cit., p. 405: La muerte del rey se considera la mayor traición, al igual que herirle: "E guardarle deuen otrosi de le baldonar. o pararse en campo para lidiar con el, porque esto seria traycion conosçida..."
} 
proximidad entre el modelo de definición del poder monárquico y el conocido para las jerarquías naturales.

\section{REACCIONES SOCIALES. LAS PRIMERAS HERMANDADES}

La situación había cambiado sustancialmente tras las medidas tomadas por el rey Sabio. Su determinación de lograr la uniformidad normativa y el deseo de acercarse al grupo de los caballeros-villanos se consideró una amenaza para el difícil equilibrio social, que en los últimos tiempos había atravesados por períodos de violencia. En efecto, la oposición entre caballeros y jerarquías naturales no se traducía en un enfrentamiento radical en todos los concejos. Algunos de estos milites o caballeros coincidían ademas en ser omes buenos y por lo tanto se integraban en el grupo próximo a las jerarquías naturales. No olvidemos que la condición de caballeros iba asociada a su actividad de hombre de armas o milites que estos desempeñaban en el concejo y al servicio del rey.

Durante una primera etapa que podríamos prolongar hasta fines del siglo XII las diferencias y oposición entre caballeros y hombres buenos pudieron quedar amortiguadas y compensadas en el interior del concejo, por los resortes y posibilidades que ofrecía la situación en la frontera y el control del territorio sobre el que se asentaba su población. Los privilegios reales y el arropamiento de una sociedad cada vez más feudalizada favorecían a los caballeros y gracias al apoyo eclesiástico para romper ataduras con sus propias parentelas y la fortuna acumulada que les permitiría organizar su propio grupo familiar de poder, ampliado por apaniaguados y excusados, otorgados por los privilegios reales.

Por su parte, las jerarquías naturales de las parentelas, a quienes los textos reconocen con el apelativo de hombres buenos, también habían reforzado su posición y los fueros y privilegios les mantenían al frente de los cargos concejiles y como garantes de la paz social. Sus fortunas también se habrían incrementado por su participación en el botín y por los beneficios de las actividades agropecuarias. Su poder se reforzaba porque en muchos casos estos jefes asumían funciones de caudillaje y también ampliaban su atribuciones, gracias a las posibilidades que ofrecían las formas feudales de integración. Con esto queremos destacar que a la altura del siglo XIII resulta difícil aceptar que hubiese un enfrentamiento entre estos dos sectores sociales que representaran la modernidad de los principios feudales, por el lado de 
los caballeros, y el mundo tradicional asociado a la parentela por el de los hombres buenos. En ambos se encontraba el germen de cambio hacia una sociedad más feudalizada y en el fondo no representaban mas que dos vías de acceso hacia el mismo objetivo. El documento de 1264 puso de manifiesto la voluntad del rey de atraerse a los caballeros y ofrecerles su apoyo, para lograr con ventaja encaramarse a las posiciones de poder. Se comprende que la reacción no se hiciese esperar y que la vía utilizada fuese la organización de la hermandad en $1282^{45}$.

¿Qué era la Hermandad? Sabemos que el término se asocia a fraternitas y sugiere una forma de asociación humana de carácter horizontal, promovida con fines diversos que van desde los espirituales hasta los políticos y que no tienen que ser excluyentes. Con anterioridad a las hermandades políticas del siglo XIII están documentadas otras formas de esta misma asociación. Se conservan algunos documentos que dan cuenta del establecimiento de Hermandades entre concejos, desde fines del siglo XII, $\mathrm{y}$ atendiendo al carácter de los acuerdos y a las partes que intervienen en los mismos, se puede hacer una somera clasificación.

\section{A) Las primeras hermandades concejiles}

Los primeros casos documentados de hermandades concejiles se remontan al reinado de Alfonso VIII y se establecen entre $1188-1202^{46}$. Se trata de la hermandad establecida entre las villas de Huete, Cuenca, Cañamares, Cañete, Uclés, Ocaña, Almoguera y Zorita de los Canes. Estas ocho villas de la ribera del Tajo no actuaban como grupo solidario que buscara adoptar medidas de fuerza en época de inseguridad. Más bien parece que en este caso el rey tenia una función activa y mediaba en el acuerdo. El hermanamiento lograba formar un gran coto redondo que enlazaba comarcas económica y culturalmente complementarias. Concretamente, el sector meridional de la Alcarria, la cuenca media del Tajo y la Mancha oriental y las tierras altas de la serranía de Cuenca ${ }^{47}$. La creación de la hermandad, a los pocos años de la repoblación de algunos de los concejos participantes,

\footnotetext{
${ }^{45}$ Así lo señalamos al analizar este documento: Fiscalidad regia y sociedad, cit. p. 80.

${ }^{40}$ Milagros Rivera GarRetas. Alfonso VIII y la Hermandad de villas de la Ribera del Tajo. "AHDE" (1979). El documento sin fecha es datado por la autora al localizar a cuatro de los treinta y tres jurados, entre 1108-1202. p. 520.

${ }^{47}$ Ibiclem, p. 523-524.
} 
es una decisión interesante que abunda en lo ya expresado. Con las garantías establecidas en el documento se permitía ampliar el espacio económico y garantizar la movilidad de los vecinos por todo el territorio, de ese modo se mejoraban las condiciones económicas de todos, al ofrecer la complementariedad necesaria para mantener formas de vida económica que en estos pueblos exigían gran movilidad. Acceder a las zonas de pasto y poder hacer rozas para cultivar era todo lo que necesitaban, de ese modo se evitaban enfrentamientos y conflictos entre las parentelas de los concejos y se lograba un mayor control sobre el territorio. La movilidad era la clave que permitía controlar extensos espacios con efectivos demográficos reducidos, tal y como se había puesto a prueba en los grandes concejos de la Extremadura. En este caso se buscan efectos parecidos de eficacia y complementariedad, a partir del acuerdo de hermandad promovido por el rey que también tendría presentes las ventajas de la defensa militar ${ }^{48}$. En esa ordenación se menciona expresamente a los mercaderes que de ese modo participaban ya del acuerdo y que posiblemente fuesen judíos, según se desvela del hecho de que las caloñas por los delitos cometidos contra ellos las cobrara el rey ${ }^{49}$.

\section{B) La hermandad bilateral}

El otro modelo de hermandad se aborda con un acuerdo más complejo con el que se busca la reciprocidad en el tratamiento a los vecinos y la salvaguarda y garantía de su movilidad. Ese es el caso de las hermandades acordadas entre Ávila y Escalona, Plasencia y Escalona o Escalona y Segovia, que fueron el resultado de la voluntad de los concejos participantes. El hecho de que se acuerden siempre entre dos concejos, de que se prohiba hacer prendas de unos vecinos a otros, bajo amenaza de sanciones iguales tras la intervención de los alcaldes, y finalmente de que se busquen las mejores condiciones para la convivencia y la explotación económica de

\footnotetext{
${ }^{48}$ Ibidem, p. 530: "Quod nullus pignoret de ninguna guisa de istas villas ni de tota ribera de Taio... [3] Isti iurati pesquirant quantum est pendrado de una anno aca de unas villas ad alteras". La garantía de movilidad se aseguraba en el documento al prohibir hacer robos y tomar prendas en ningún caso en esas villas ni en la Ribera del Tajo. Los jurados nombrados por el rey se encargarían de mantener la vigilancia

"9) Ibidem, p. 530: [2] "Qui camino quebrantara o pendrare mercatores pectet I morabetinum al regi".
} 
algunos territorios, denota su marcado interés local ${ }^{50}$. Lo interesante de estas hermandades es que son acuerdos bilaterales de carácter local que tratan de proteger, en este caso, a los vecinos de Escalona de los excesos de los vecinos de los concejos próximos. En este sentido, se prueba la habilidad de Escalona que siendo un concejo de menor envergadura resuelve su problema por medio de acuerdos con concejos de mayor importancia, como son Segovia, Avila y Plasencia, logrando garantías para sus vecinos, al tiempo que esos acuerdos simultáneos evitaban los abusos y las acciones de fuerza sobre sus tierras y propiedades. Todo ello dice mucho de la habilidad política de este concejo, gracias a la cual lograban mejorar su situación por encima de sus posibilidades.

\section{C) La hermandad acordada}

En esa misma línea de acuerdos interconcejiles de defensa y equiparación se encuentran los pactos de hermandad acordada entre Plasencia y Talavera en 1248 y 1274 , para defenderse de la amenaza del concejo de Ávila que se introducía en cuña entre ambos ${ }^{51}$. Curiosamente este documento que tiene un claro fin defensivo se define en términos de acuerdo y amistad. Ahora bien, este tipo de pacto ofrece el interés de presentar a los concejos actuando como instituciones y poderes capacitados en una dimensión nueva, referida abiertamente a los conflictos interconcejiles. Sorprende que, a diferencia de las hermandades de 1200, no se haga alusión a los vecinos ni a sus responsabilidades, y que el protagonismo lo tengan los concejos de Talavera y Plasencia que, en representación de los vecinos, acuerdan un pacto contra el concejo de Ávila y contra todos los que viniesen con él. La búsqueda de ayuda mutua en casos concretos de amenaza exterior presenta a los concejos asumiendo la responsabilidad de entablar un acuerdo y pacto de "bona amizdad". Es interesante también que en esta ocasión los acordantes se centren en los compromisos de ayuda mutua y amistad, dejando a salvo los derechos del rey, a quien se refieren en términos de

\footnotetext{
${ }^{50}$ Claudio SÁnChez AlBornoz, Carta de Hermandad entre Plasencia y Escalona, "AHDE" (1915), pp. 504-508. La carta la fecha hacia el año 1200. En el mismo sentido están redactadas las que Escalona establece con Ávila y con Segovia publicadas por Luis SUÁrez FERNÁNDEZ, Evolución histórica de las hermandades, cit, pp. 46-47 y 50-51.

${ }^{51}$ Juan Ignacio RUIZ DE LA PEÑA, Aportación al estudio de las Hermandades concejiles en León y' Castilla durante la Edad Media, "Homenaje al Profesor Juan Torres Fontes", 2 (1987) 2. pp. 1512-1513. El acuerdo no se califica expresamente de Hermandad.
} 
señor $^{52}$. En 1274, estos dos concejos acuerdan un nuevo pacto al que ya denominan hermandad y que tiene un carácter más amplio, ya que no se centra en la defensa de los ataques de Ávila sino que se expresa de un modo genérico frente a todos los hombres del mundo, y los concejos que les atacasen. En esta ocasión, se incluyen menciones a la necesidad de agilizar los trámites ante las reclamaciones que hiciesen los vecinos y ya no se menciona al rey. Este acuerdo privado parece que perfecciona el de 1248 y lo generaliza frente a concejos y otros hombres que pusiesen en peligro la seguridad de los hermanados. Es posible que este tipo de pactos proliferera en la zona y sirviera tanto para proteger de las amenazas de otros concejos como de las provenientes de los caballeros y otros poderosos de la zona. En este sentido, la hermandad acordada sería una apoyatura frente a posibles amenazas e intentos de acabar con el status quo que reinaba en la política interna.

\section{D) Las hermandades politicas}

Son otro llamativo ejemplo de hermandad local, que se documenta en Asturias en 1277 y unía a los concejos de Avilés, las Pueblas de Pravia, Grado, Salas, Somiedo, Valdés, Tineo, Cangas y. Allende ${ }^{53}$. Se trata de una federación de concejos y de un acuerdo de ampliación de la vecindad entre los firmantes, pactado bajo los auspicios y el estímulo real, y hecho con el propósito de evitar los males que ricos hombres y caballeros pudieran hacer tanto a la tierra como al rey. Este diploma tiene la originalidad de unir la defensa del territorio y los vecinos de los concejos hermanados con la causa del rey, y, en ese sentido, establece que el delito cometido se valore como deserviçio del rey ${ }^{54}$. El apoyo al rey y a su causa se puede poner en

\footnotetext{
52Ibídem: "Con sabor de fazer mejor uida de consuna e por nos defender a muchas fuerças e a muchos tuertos e a muchas soberuias que sofrimos e auemos sofrido grant sazon ha de muchas guisas del concejo d'Avila y contra quantos en su ayuda uinieren.

Que el concejo de Plazencia y el concejo de Talauera se ayuden en todas cosas cada que el un concejo lamare al otro...e por que de nenguno non sea calonnada nuestra bona amizdad en nuestra postura, entendemos todos los derechos del sennor salvos".

${ }^{53}$ Eloy, Benito RuANo, Hermandades en Asturias durante la Edad Media, Oviedo, Instituto de Estudios Asturianos, 1971, pp. 56-58.

${ }^{54}$ Ibidem, p. 57: "Et esto estaulecemos por guarda de noso sennor el Rey... e que non auria entre nos rico omme nen cauallero nenguno de los que fezieren deseruicio a nuestro sennor el Rey, et para quel caso que entrás que dian luego apellido a los otros concellos, en guisa que podamos seer juntados para defender e guardar la tierra de noso sennor el Rey".
} 
relación con los problemas sucesorios que se desatan en la Castilla de Alfonso X, a partir de 1275 y tras la muerte del heredero, el Infante don Fernando de la Cerda, la amenaza de los benimerines y la del rey de Francia ${ }^{55}$. El otro aspecto destacable de esta hermandad es la voluntad de mantener reuniones periódicas, a las que enviarían a dos hombres buenos, en el lugar de La Espina para atender sus asuntos y actuar al servicio del rey. Se trata de una nueva conquista en la capacidad de acción política de los concejos que hacían de la hermandad el elemento de proyección, al tiempo que les fortalecía frente a los enemigos y amenazas más inmediatos. La hermandad era la gran baza política de los hombres buenos, tal y como se demostraría en los años siguientes.

Estos modelos de hermandad concejil prueban el desarrollo que esta institución había tenido durante la primera parte del siglo XIII y como habría ido ganando en capacidad de acción y diversidad, hasta constituirse en una federación con fines políticos claros, en defensa de la causa del rey. Esto prueba la paulatina madurez de los concejos y su capacidad de adaptación a las diferentes circunstancias, que culminaría en ese acuerdo de federación con clara intencionalidad de compromiso político. Este primer desarrollo de las hermandades explica su proliferación y su importancia a partir de 1282 .

\section{LA HERMANDAD DE 1282. EL PAPEL DE LA NOBLEZA}

La dimensión política de las hermandades en la Corona de Castilla no se manifiesta hasta los últimos años del reinado de Alfonso $\mathrm{X}$ y se relaciona con la llamada primera hermandad de 1282 . Se trata de la primera implicación de envergadura asumida por los concejos del reino para decidir asuntos de alta política, en este caso para colocarse al lado del rey Alfonso $\mathrm{X}$ o al lado de su hijo Sancho IV. Los concejos tenían sus propias razones de implicación para dar este paso y además habían ensayado fórmulas de asociación en los modelos de hermandad ya comentados. En Castilla y León los concejos se integraron en la hermandad nobiliaria en julio de 1282 y los

\footnotetext{
${ }^{55}$ Joseph F. O Callaghan, El reinado de Alfonso X, cit., pp. 292. Tras finalizar las cortes de Burgos de 1277 y conocer los peligros que amenazaban al reino se organizadon hermandades como la de las villas de Asturias.
} 
documentos conservados reflejan las dificultades asociadas a la toma de una decisión de tal envergadura ${ }^{56}$.

Sabemos que el 8 de julio de ese año se lograba un compromiso de ayuda mutua entre la hermandad de León y Galicia y la de Castilla ${ }^{57}$. En el diploma que recoge el acuerdo se da cuenta de cómo el infante don Sancho nuclearizó el movimiento en torno a sus aspiraciones al trono, y a él se le pide la vuelta al respeto de los fueros, privilegios, usos y costumbres de tiempos del rey don Alfonso VIII. El momento se aprovecha también para hacer una nueva definición de las obligaciones de los concejos hacia el monarca que venían a ser: el ejercicio y preservación de la justicia, por razón del señorío del rey, el pago de la martiniega, la moneda forera, el yantar una vez al año o cuando viniesen al lugar y la fonsadera cuando fuesen en hueste, tal y como lo solía dar según el fuero. Todo lo cual suponía una vuelta a los viejos usos y costumbres que se consideraban vulnerados durante el reinado de Alfonso X.

Tal y como se indica en la primera parte de este diploma, la incorporación de los componentes de la hermandad de León y Galicia se unía a la del reino de Castilla, ya constituida. Se trata pues de un documento de pacto entre dos hermandades que no adopta la forma de acuerdo entre iguales sino que se resuelve en un contexto feudal de relaciones jerarquizadas, y eso se traduce en el hecho de que la hermandad de Galicia hace pleito homenaje a la hermandad del reino de Castilla. Se incorporan así colectivamente por la vía del vasallaje y se comprometen a respetar el acuerdo, bajo la amenaza de terribles penas en caso de no cumplirlo ${ }^{58}$. El lenguaje y los términos feudales impregnan este acuerdo y le aportan algo de la majestuosidad de los tratados, pero también puede querer indicar un criterio jerárquico

\footnotetext{
${ }^{56}$ En Andalucía sabemos que la inquietud había llevado a algunos concejos a hermanarse en la primavera de este mismo año. Los concejos de Jaén, Baeza, Úbeda, Andújar, Arjona y Santisteban establecieron una hermandad en apoyo de Sancho. Ver Joseph F. O CallaGHaN, El reinado de Alfonso $X$, cit., p. 312 y nota 40 .

${ }^{57}$ Conocemos el acuerdo a través del documento que se conserva en el Archivo Municipal de Nájera, publicado por César GonzÁlez Mínguez, Aproximación al estudio, cit., pp. 54-58. Otra copia de este mismo documento más incompleta es la que ofrece Antonio ÁlVAREZ DE Morales, Las Hermandades, cit. , apéndice I pp. 267-268.

${ }^{58}$ Ibidem, p. 58: "E nos toda la hermadat de Leon e de Galiçia façemos pleyto omenaie a toda la hermandat del regno de Castiella de uos ayudar bien $/^{51}$ e lealmente e guardar e mantener todas estas cosas sobredichas e cada una delas. E si asi non lo feçieremos que seamos traydores por ello como quien mata sennor e trae castiello e nunca ayamos manos nin armas nin len- $/ /^{52}$ guas con que nos podamos defender".
} 
tal y como sugiere la mecánica feudal. En ese caso sería la hermandad de Castilla la primera en formarse y a ella se añadirían las de otros reinos o regiones, tales como las de los reinos de León y Galicia, pero esta fórmula permitiría que también se le unieran otras hermandades menores como la de Segovia y las villas de su obispado con el maestre de Santiago, o las de las villas de Andalucía, si bien de estas uniones no ha quedado constancia.

Este documento constituye la primera manifestación de voluntad de los concejos para plantear una serie de reclamaciones ante el débil poder regio, representado por el infante don Sancho en sus aspiraciones al trono frente a sus sobrinos los infantes de la Cerda. El acuerdo adoptaba la forma de una conjuratio y en el los concejos se organizaban como una sociedad de defensa mutua para mantener sus fueros, ser capaces de enfrentarse al rey si violaba su compromiso de respeto, y defenderse de las amenazas exteriores y también para prevenir las defecciones y traiciones desde el interior $^{59}$.

La hermandad trabada en 1282 se convirtió en una estructura de poder con amplia proyección sobre el territorio y que reservaba un gran protagonismo a los concejos, ya que las tierras de realengo en ese momento suponían la gran parte del reino, en comparación con el abadengo o el señorío. Pero tal y como se ha dicho ese acuerdo supuso el revés a la política de cambios organizada por Alfonso X a lo largo de su reinado, unos cambios que fueron frenados para volver a los viejos usos y costumbres en una actitud claramente conservadora. La adhesión de las ciudades a la revuelta se explicaría por el rechazo a la política fiscal, a los intentos de unificación del derecho y también a la política de privilegios hacia los caballeros practicada por rey Alfonso $X^{60}$. La dinámica en la que se fueron desarrollando las hermandades ofrecería a los concejos la oportunidad de desempeñar cierto protagonismo político que hasta entonces las otras hermandades no habían tenido.

Ahora bien, en este documento de 1282 observamos que diferencia con nitidez a los dos sectores que componen la oligarquía y en ocasiones encarga a los miembros de los mismos determinados asuntos ${ }^{61}$. Mientras los

\footnotetext{
${ }^{59}$ Ibidem, pp. 54-57.

${ }^{60}$ César González Mínguez, Aproximación al estudio, cit., p. 48

${ }^{61} I$ bídem, p. 57: "Otrosi que si el rey don Sancho o los otros reyes que seran en pues ellos enuiaren por alguno qualquier de la hermandat o ellos vinieren al logar e los ommes de aquell llogar entendieren que envian por el $38 /$ e por le facer malque enuien dos caualleros o dos
} 
omes buenos son los que figuran con responsabilidades y hasta es el término que sirve también para reconocer a los miembros de la hermandad ${ }^{62}$, las menciones a los caballeros se hacen junto a las de los infanzones, ricos hombres y otros posibles enemigos o amenazas de sus acuerdos ${ }^{63}$. Se consideraba entonces que este sector social asociado a la nobleza y al oficio de las armas podría constituir su mayor peligro. Eso no significa que no hubiese otros caballeros apoyando a la hermandad, como hombres de armas que formaban parte del concejo y asumían los postulados de la hermandad. Pero si cabe pensar que en su mayoría no se encontraran atraídos por la hermandad de 1282 , porque considerarían que la vuelta a los fueros y los viejos usos les privaba de fuerza y apoyos políticos para su propósito de dominar los gobiernos concejiles.

Ya en abril algunos concejos se integraban en la hermandad, unidos a algunos de los grandes nobles del reino, cuyos señoríos se encontraban en zonas próximas. Así, sabemos que villas andaluzas de Córdoba, Jaén, Baeza, Andujar, Arjona y San Esteban hicieron hermandad con tres nobles: Gonzálo Yañez de Aguilar, Sancho Sánchez de Jódar y Sancho Pérez de Jódar, a los que se unieron para reconocer al infante don Sancho, del que se hacían vasallos y colocaban bajo su señorío sus villas y castillos ${ }^{64}$. Con la hermandad se proponían la defensa de los fueros y libertades, buenos usos y costumbres, con obligación de ayuda mutua y graves penas para los que no acudiesen a las llamadas de auxilio, al tiempo que se establecía un principio para dirimir las contiendas y conflictos que pudiesen surgir entre los firmantes. De ese modo, disponen que en caso de enfrentamientos entre los señores fuesen dos de los concejos no implicados los que se encargaran de juzgarlo, y los demás se comprometiesen a cumplir la sentencia. En caso de peleas entre los concejos se practicarían sanciones simbólicas como cortar la cola del caballo si fuese un caballero, y si fuese un peón que le rapasen

ommes dese conçeio al rey o a don Sancho o a los otros reyes que seran.."

${ }^{62}$ Ibídem, p. 57: "Otrosi ponemos $/^{47}$ que llos de la hermandat que fueren a las vistas ali do se juntaren los ommes buenos de la hermandat que uayan seguros por tres semanas de yda e por tres de morada".

${ }^{63}$ Ibídem, p. 56: "Otrosi que ningun infante nin rico omme non sea merino nin adelantado en el reyno de Leon e de Galiçia nin infançon nin cauallero $/ 29$ que aya gran omiçilio sabudo con caualleros"

${ }^{64}$ Joseph F. O'Callaghan, El reinado de Alfonso X, cit.,, p. 312. La carta de Hermandad lleva fecha de 10 de mayo de 1282. El documento se conserva en el Memorial Histórico Español, III, Madrid, 1852, doc. CCV, pp. 72-74. 
el pelo en forma de cruz. Se arremete también contra las cartas desaforadas, que debían proliferar como resultado de los privilegios de los últimos años, y se dispuso que se castigaría con la lapidación a aquel que las trajese o las apoyase. Acordaron finalmente celebrar una reunión anual, dos semanas después de la Pascua mayor, en Andújar, y debían de acudir a ella dos caballeros de cada concejo y los señores ya mencionados ${ }^{65}$. Interesa destacar el carácter del pacto entre iguales de esta primera hermandad andaluza de 1282, entre los nobles firmantes y los concejos que actuarían como señoríos colectivos. Esa equiparación de los firmantes tuvo que ser necesariamente corregida acto seguido para dejar constancia de los derechos que los concejos de Córdoba, Jaén y Úbeda mantenían sobre Aguilar, Arjona y San Esteban, porque estos habían sido sus castillos y podían demandarlos siempre que quisiesen. Eso reducía el número de los verdaderos protagonistas a los tres grandes concejos y a los tres señores ${ }^{66}$. Es interesante la mención que se hace a los caballeros como representantes de estos concejos andaluces, en los que no figuraban los hombres buenos, lo que se justificaría por el carácter tardío de la repoblación de esta zona y la firme implantación de los caballeros como grupo oligárquico.

Por una vía similar, se integra el concejo de Segovia y las villas de su episcopado en la hermandad, el 10 de julio de 1282, cuando la acuerdan con don Pedro Nuñez, maestre de la Orden de Santiago. En este caso, el documento da cuenta de cómo a causa de la situación extrema a la que se había llegado, se habían juntado en torno al infante don Sancho algunos de sus parientes, ricos hombres, prelados, maestres de las Ordenes, caballeros y hombres buenos de las villas, todos de común acuerdo, para mantenerse en sus fueros tal cómo el infante don Sancho les había asegurado ${ }^{67}$.

Parece indiscutible que los hombres buenos de los concejos disponían de razones propias para entrar a formar parte de la hermandad, debido a la

\footnotetext{
${ }^{65}$ Ibidem, p. 74: "E otrosi ponemos, que ayamos junta cada año una vez en Andujar a quince dias despues de la Paschua maior, e que vengan y dos cavalleros de cada consejo, e Gonzalo Ibañez e Sancho Sanchez e Sancho Perez por sus personas.."

${ }^{6}$ Ibidem, doc. CVI, pp. 74-75, 10 de mayo de 1282: "nos todos estos sobredichos otorgamos, que como quier que nos ficiemos nuestra hermandad entre nos assi como dicen las cartas que avemos en uno, ponemos entre nos que finquen en salvo los de Cordova todo el derecho que han en Aguilar, e los de Jaen todo el derecho que han en Arjona, e los de Ubeda todo el derecho que han en Sant Esteban, por razon que alegaron que fueron sus castillos privilegiados, e que lo demanden cuando quisiseren".

${ }^{67} \mathrm{El}$ acuerdo se transcribió en el apéndice documental de nuestro trabajo Fiscalidad regia y sociedad, cit. pp.83-84.
} 
fuerte presión fiscal a que se había sometido al reino después de 1275, y también por la amenaza que los códigos del rey representaban para el derecho y las costumbres locales. Pero la oportunidad del momento y la decisión de organizar una gran hermandad fue algo que les vino dado por la alta nobleza. No cabe duda del protagonismo de la nobleza en la gestación de ese movimiento de revuelta que conocemos como hermandad, y además la inclusión de algunos concejos se hizo de la mano de alguno de los grandes nobles, que de ese modo extendían los acuerdos de Valladolid, pactados entre los grandes del reino y el infante don Sancho. Aunque los documentos analizados apenas se refieren a la nobleza como parte activa en su surgimiento, eso no nos debe hacer olvidar que el peso de la revuelta en los últimos años del reinado de Alfonso X lo tuvo la alta nobleza laica y eclesiástica. Su papel fue definitivo en la organización de la hermandad de 1282 y se destacó en algunas zonas, en las que los grandes nobles se aliaron en hermandad a los concejos. Es muy posible que los nobles, que tenían mayor experiencia de intervención política y también una concepción global del reino, animaran y organizaran la formación de una hermandad general con la participación de los concejos, un hecho sin precedentes hasta la fecha.

Tras la muerte de Alfonso X en abril de 1284, las hermandades mantenían su vigencia y así lo manifestaban en los acuerdos tomados en Medina del Campo en septiembre de 1284. En los apartados del mismo se vincula la actividad vigilante de la hermandad con las Cortes a las que se comprometían a enviar dos ommes buenos de cada concejo, allí a donde el rey les convocase. El ordenamiento de la hermandad incluía, junto al propósito de defender los fueros y privilegios, el de condenar a aquellos que desde dentro de los concejos quisiesen ir contra la hermandad, y por último se adquiría el compromiso de acudir a la convocatoria anual de Sahagún para el día de San Miguel, el 29 de septiembre, a la que enviarían a los ommes buenos de cada lugar ${ }^{68}$.

Los concejos habían logrado una participación activa en la política del reino y eso había favorecido alcanzar un mayor grado de conciencia acerca de su poder e influencia política. Se utilizaba para ello un lenguaje con una terminología característica y fuertemente impregnada de terminos feudales, al tiempo que se desplegaban símbolos tales como los sellos 26.

${ }^{68}$ Ibidem, pp. 58-60, Medina del Campo 8 de septiembre de 1284. Líneas 5-6, $18-19$ y $25-$ 
concejiles, que validaron algunos de los acuerdos, o el propio sello de la hermandad de Galicia descrito en el documento. El sello estaba dispuesto sobre dos caras que representaban a un León por un lado y por el otro la figura de Santiago, montado a caballo y llevando una espada en la mano derecha, y una bandera con una cruz en la izquierda.

Entre 1282 y 1284 las hermandades tuvieron que cubrir la seguridad y el control de su territorio y eso pudo favorecer la ampliación de la hermandad a aquellos concejos que se hubiesen mostrado reticentes. Conocemos que la hermandad de León y de Galicia mantuvo una actividad de amparo y protección, documentada en 1283 para proteger al convento de San Vicente de Monforte, que habían sufrido los abusos de caballeros, escuderos, dueñas y otros hombres que les habían robado ${ }^{69}$. De ese modo se fue potenciando la faceta de salvaguardas del orden y de freno a los abusos de los malhechores feudales.

\section{LAS HERMANDADES DESDE 1295. TIPOS Y CONTENIDOS}

El reinado de Sancho IV que se había establecido gracias al apoyo que le dio el descontento y la reacción a las innovaciones de su padre, muy pronto se vio en la necesidad de poner coto a algunas de propuestas surgidas en el último período, e ir introduciendo algunos cambios claramente inspirados en las teorías de Alfonso X, eso sí, convenientemente maquilladas $^{70}$. Sancho IV suprimió la hermandad en 1284 acontecimiento que se produjo a buen seguro en las Cortes de Valladolid, convocadas a principios del mes de diciembre, resultado de una decisión airada de respuesta real a las propuestas acordadas en Medina del Campo que ya hemos comentado ${ }^{71}$.

La política anti-hermandad de Sancho IV se justifica sobre todo porque el monarca probaba a actuar en diversos frentes, procurando atraerse a la nobleza, por medio de grandes pactos con sus cabezas más destacadas,

\footnotetext{
${ }^{69}$ Memorial Histórico Español, II, Madrid, 1852, doc. CCXXIV, pp. 102-103.

${ }^{70} \mathrm{El}$ breve reinado de Sancho IV (1284-1295) cuenta con importantes trabajos como el ya clásico de Mercedes GAIBROIS DE BALLESTEROS, Historia del reinado de Sancho IV de Castilla, 3 vols Madrid, 1922-1928 y el reciente de José Manuel NIETO SORIA, Sancho IV. 1284-1295, Palencia, 1994.

${ }^{71}$ Esta decisión se considera la prueba de que el rey estaba en el convencimiento de que la conveniencia política estaba por encima de cualquier agradecimiento. Ver José Manuel NiETo SORIA, Sancho IV, cit., p. 63.
} 
y para la Iglesia con una oferta de colaboración regia en la recaudación de los impuestos eclesiásticos y la en la mediación en los conflictos que algunas ciudades episcopales mantenían con sus obispos ${ }^{72}$. Además se vio obligado a buscar un acercamiento a los caballeros del reino, tan necesarios para organizar las campañas en la frontera o para frenar al rey de Aragón y a los infantes de la Cerda en sus pretensiones al trono de Castilla. En consecuencia, practicó la política de concesión de privilegios a los caballeros que había caracterizado al reinado de Alfonso $\mathrm{X}^{73}$. Con la hermandad suprimida, el apoyo a los caballeros aportaba nuevas energías a las pretensiones de exclusivo poder oligárquico de este grupo social, en el seno de sus respectivos concejos. Eso también les hizo fuertes para reclamar un mayor protagonismo en la segunda fase de constitución de hermandades, que se produjo en 1295, a la muerte del rey Sancho.

\section{A) La hermandad de 1295 y las hermandades locales}

La prematura muerte del rey Sancho IV dejó al reino en una situación precaria, con amenazas exteriores y en el interior tensiones y conflictos, derivados de la ambición nobiliaria y de las diferencias que en el seno de los concejos seguían enfrentando a caballeros y hombres buenos. Sobre esta cuestión cabe suponer que si la organización de la hermandad había reforzado la posición de los hombres buenos, su supresión y la solicitud que Sancho IV mostraba hacia los caballeros habría reforzado a los hombres de armas en sus pretensiones de poder. El 25 de abril falleció el rey y el 6 julio de 1295 documenta Benavides la constitución de la hermandad de los concejos de Castilla, el 12 de julio la de los concejos del reino de León y Galicia, y el 3 de agosto la establecida entre los concejos de Extremadura y el arzobispo de Toledo ${ }^{74}$.

\footnotetext{
${ }^{72}$ Ibidem, pp. 214-220.

${ }^{73}$ En Burgos, 18 de agosto 1289 concede a los caballeros de Ciudad Rodrigo privilegios de exención de todo pecho a los amos que críen a sus hijos, por haberle acompañado en hueste a Aragón. Ver Ángel Barrios, José María MONSAlvo y Gregorio del SER, Documentación medieval del archivo municipal de Ciudad Rodrigo, Salamanca, 1988, doc. 11, pp. 23.

${ }^{74}$ Por el orden mencionado ver: Antonio BEnAvides, Memorias de Fernando IV de Castilla, II, 1860, no 111, pp 3-7. Luis GarCía DE VALDEAVELlano, Carta de Hermandad entre los concejos de la Extremadura castellana y del Arzobispo de Toledo en 1295, "Homenagem ao Doutor Paulo Merêa. Revista Portuguesa de História", 12 (1969), pp. 69-76 y Pascual Martínez Sopena, Privilegios reales de la villa de Benavente (siglos XII-XIV), Benavente, 1996, pp. 27-31.
} 
Cabe suponer que las hermandades surgieron casi de un modo espontáneo e inicialmente aparecieron como hermandades locales que agruparon a dos o tres concejos, con la finalidad primordial de garantizar el orden en la zona y perseguir a los delincuentes. Con esos objetivos se constituyeron en hermandad los concejos de Salamanca, Alba de Tormes y Zamora el 17 de mayo de 1295. En la carta de acuerdo aseguraban que su propósito era acatar al rey niño, don Fernando, y ponerse a su servicio, y que también lo hacían por temor a recibir daño de algunos hombres en sus villas y en sus términos respectivos. Por ello acordaban castigar a aquellos que desde dentro o desde fuera de sus villas les atacasen, lo mismo que a los concejos que se aliasen con otros para hacerles robos y daño. Se prometían apoyo mutuo, que llegaría a cada concejo antes de tres días, y se daban capacidad para poder hacer prendas en los concejos de los que fuese el acusado. Añadían que si en relación con lo acordado acaeciese muerte $\mathrm{u}$ homicidio, los concejos se atuviesen a la consiguiente responsabilidad ${ }^{75}$. Resulta llamativo el hecho de que el acuerdo mencionado se centre en aspectos de defensa, tanto de enemigos interiores como exteriores, y que no se haga alusión a los fueros ni privilegios, en ningún caso. Se trataría de una hermandad pactada con unos objetivos limitados de la que se habían excluido asuntos que probablemente no contaban con la aquiescencia de todo el concejo, para evitar tensiones internas, y la razón podría ser la fuerza que en su seno habían logrado los caballeros. De hecho, los garantes de lo acordado eran dos caballeros de los respectivos concejos, tal y como se especifica al final del documento ${ }^{76}$. La constitución de asociaciones como esta tiene el interés de mostrarnos que el modelo de hermandad seguía siendo útil a diferentes fines y que la instauración de las grandes ligas políticas no había hecho olvidar que también se podían hacer acuerdos de menor envergadura pero posiblemente de mayor eficacia. En este caso, los caballeros de los concejos de la Extremadura leonesa se aseguraban en el poder gracias al refuerzo del control del territorio que les proporcionaba el acuerdo de hermandad.

\footnotetext{
${ }^{75}$ Angel Barrios, Jose María Monsalvo y Gregorio del SER, Documentación medieval del archivo municipal de Ciudad Rodrigo, cit., doc 18, pp. 59-61.

${ }^{76} I$ Ibidem, p. 61: "Et, si por aventura sobre estas cosas o sobre algunas dellas acaeçiere dubda, que dos cavalleros de Çamora e dos de Salamanca e dos de Alva que lo libren en aquella manera que fallaren que es derecho; e nos estemos por lo que ellos mandaren".
} 
La reacción de la hermandad de los hombres buenos de Castilla, basada en los principios que la habían justificado en 1282, no se hizo esperar y apareció el 6 de julio de ese año. El documento manifestaba que se constituía por los muchos desafueros e injusticias, muertes y prisiones que habían recibido del rey don Alfonso y del rey don Sancho, su hijo. Aseguraban haber obtenido confirmación de sus fueros y privilegios del rey don Fernando y se comprometían en el servicio al rey, y en asegurar y guardar su tierra. Eso daba pie a plantear de nuevo los límites al señorío del rey y comprometerse al pago de marzàdga, moneda, yantar y fonsadera, como se solía hacer. A continuación, se condenaban los contrafueros, la toma de prendas, los desafíos y las muertes y se aseguraba que en todos esos casos la hermandad intervendría para ayudar a los damnificados. En el caso de que algún rico hombre o cualquier otro hombre de fuera matase a uno de los miembros de la hermandad, incluso en el caso de que ni el fuero ni el juez le determinasen como enemigo, la hermandad se volcaría como un solo hombre y le tendría por su enemigo. Con esta disposición la hermandad se colocaba por encima del fuero y de los jueces para proteger a sus miembros de la violencia ${ }^{77}$.

También la hermandad se enfrentaría al rey y limitaría sus exigencias fiscales, ya que dispuso que no se paguasen ni pechos, ni pedidos, ni préstamos ni diezmos que fuesen contra el fuero y que aquellos que trajesen las cartas de petición que recibiesen pena de muerte por ello. Añadían que si el rey Fernando o alguno de sus sucesores quisiese pedir algún préstamo a algún concejo, que este no se lo diese a no ser que fuera aprobado por toda la hermandad.

Se afirmaba el compromiso de mantener reuniones periódicas de la hermandad en Burgos, ocho días después de la Pascua de çincuesma o del Espíritu Santo y enviar a las mismas a dos hombres buenos cada concejo, bajo amenaza de pagar mil maravedíes de multa en la primera falta y dos mil a la segunda, con agravante de que cayesen en pena de perjurio y de ruptura del homenaje, según el código feudal. Se preocuparon también de asegurar que cuando los concejos de la hermandad enviasen a dos hombres buenos, como representantes a las reuniones de Cortes, eligiesen a los mejores, para que todo se hiciera a mejor servicio del rey y a favor del concejo que representaba.

\footnotetext{
${ }^{77}$ Antonio Benavides, Memorias de Fernando IV de Castilla, II, 1860, "nº 111, pp 3-4.
} 
La carta del pacto de hermandad celebrado en León la conocemos a través de la copia enviada a Benavente y se plantea en unos términos similares a los ya señalados para la de Castilla ${ }^{78}$. Incluso las reuniones que debían de celebrarse en León, tendrían lugar el mismo día y con la misma periodicidad. Sí cabe destacar que en este documento hay más menciones a los hombres buenos que en el de Castilla, aunque mantienen las mismas competencias. El documento lo asumían treinta y dos concejos del reino de León y de la Extremadura leonesa. Otras hermandades se pactaron en Andalucía y Murcia en agosto y octubre del mimo año ${ }^{79}$.

Por último, la carta de hermandad hecha entre los concejos de la Extremadura castellana y del arzobispo de Toledo ofrece el interés de ser casi una hermandad general del reino por el número y la importancia de los firmantes, entre quienes se cuentan cuatro obispos, los de Osma, Avila, Segovia y Sigüenza, y un arzobispo. Aunque en su contenido es muy similar a los anteriormente comentados, con marcadas referencias a la defensa de los fueros y el protagonismo destacado de los hombres buenos, que también serían los representantes en las Cortes y en la hermandad ${ }^{80}$.

Resulta interesante observar que el número de los que se incluyen como miembros de la hermandad suman treinta y tres concejos y cuatro jerarquías eclesiásticas: el arzobispo de Toledo y diez concejos de la zona, el obispo de Osma con siete concejos y un vasallo, el obispo de Sigüenza con ocho, el obispo de Segovia con otros ocho concejos. A continuación figuran los de la hermandad de Castilla con sesenta y tres concejos firmantes y finalmente la hermandad de León con treinta y cuatro. Cada uno de los concejos tenía uno o más representantes que aparecen con sus nombres. Este documento prueba la importancia de la hermandad de 1295, avalada por las numerosas adhesiones que había logrado y acompañada de una espectacular exhibición de fuerza que suponía reunir a concejos y obispos en una gran alianza. Pero también llaman la atención determinadas ausencias que no

\footnotetext{
27-29.

${ }^{78}$ Pascual Martínez Sopena, Privilegios reales de la villa de Benavente, cit., doc. 7, pp.

${ }^{79}$ César González Mínguez, Aproximación al estudio, cit., pp. 36-37. Señala que el texto de la hermandad de Murcia es casi idéntico a la de León, mientras la de Andalucía incluye aspectos que destacan el peligro de la frontera. Ver también el trabajo de Manuel García FERNÁNDEZ, La Hermandad General de Andalucía durante la minoría de Alfonso XI de Castilla: 1312-1325, "Historia. Instituciones. Documentos", 12 (1985), pp. 351-75.

${ }^{80}$ Luis García de Valdeavellano, Carta de Hermandad entre los concejos de la Extremadura castellana cit., pp. 69-74.
} 
parecen fáciles de explicar, como las e Segovia y Ávila, dos concejos señeros del ámbito extremadurano. La razón del por qué no figuraron en este acuerdo de 1295 habrá que atisbarla en razón de la propia estructura y construcción social interna de estos concejos, en los que el predominio de los caballeros villanos era muy destacado a fines del siglo XIII ${ }^{81}$. Ciertamente la situación política favorecía la división en el seno de los concejos y la proyección a escala local de las luchas en bandos, muchos de los cuales escondían la vieja rivalidad entre caballeros y hombres buenos. No cabe suponer que los concejos mimetizasen las luchas que la reina mantenía con los parientes de Sancho IV y en consecuencia que el reino y los concejos se enfrentasen por esa sola razón ${ }^{82}$. Como en tantas otras ocasiones la división política en la cúspide del poder favorecía la polarización en el seno de las villas y ciudades, que a su vez reproducían divisiones internas de bandos afines como síntoma de la conflictividad social y económica que vivía el concejo.

Otras formas de hermandades surgidas entre 1295 y 1296 nos ilustran acerca de la versatilidad de esta forma asociativa, al tiempo que descubrimos cómo tras la formación de una hermandad se modificaban algunas circunstancias que hacían temer a los señores que su dominio podría peligrar. Sobre este segundo aspecto, recordemos que ya el caso de la hermandad de las villas andaluzas de 1282 dio lugar a la aclaración en un segundo documento, de la especial vinculación que tres de las villas y sus fortalezas mantenían con las ciudades de Córdoba, Úbeda y Jaén ${ }^{83}$. Eso hace pensar que algo podía modificarse en las relaciones de poder sobre el territorio, a partir del momento que se había constituido una hermandad y en este sentido se podrían explicar las precauciones que en 1295 tomó el arzobispo de Toledo al exigir a los firmantes de la hermandad de Extremadura que los concejos de Alcalá, Brihuega, Uceda y Talamanca, que eran sus

\footnotetext{
${ }^{81}$ En el caso de Segovia, la crónica menciona la división interna que había en la ciudad en dos bandos, uno favorable al infante don Juan, capitaneado por Día Sanz, y otro a la reina doña María de Molina, al frente del cual estaba Diego Gil. Ver Crónicas de los Reyes de Castilla, I, Madrid BAE, 1953, p. 10. Los episodios de enfrentamiento entre los caballeros y los hombres buenos los documenta mejor Diego de COLMENARES y tuvimos ocasión de analizarlos en nuestro trabajo: Segovia. La ciudad y su Tierra a fines del Medievo, Segovia, 1986, pp. 286288.

${ }^{82}$ César González Minguez, Fernando IV (1295-1312), Palencia, 1995, p.34. Considera que la situación vivida en Palencia, al igual que la de Segovia, se explica por la división entre los dos bandos de partidarios de Fernando IV y del infante don Juan.

${ }^{83}$ Ver nota 66
} 
vasallos y habían entrado en la hermandad de Extremadura, no fueran a aprovechar la situación en merma de su señorío, y que en caso de que lo intentasen no les proporcionaran ayuda ${ }^{84}$.

En 1296 surgieron otras hermandades locales que se acordaron en el seno de un mismo concejo con el objetivo de asegurar la defensa y el servicio del rey. Este es el caso de la hermandad de Talavera del 11 de marzo de 1296 y la de Cuenca del 10 de abril del mismo año. En el documento de Talavera se dice que el rey Fernando IV, tras recibir a Gonzalo Yañez y a Lorenzo Venegas, caballeros de Talavera "de una parte" y a Juan Simón y Ruiz Martínez también caballeros del mismo lugar "de la otra", razonó con ellos lo que más convenía al rey y a esa villa, para lo cual les recomendó que "se asegurasen e que se amasen bien e derechamente e se ayudasen unos a otros contra todos aquellos omes o mugeres del mundo que fuesen contra ellos e contra su villa e nuestros servicios" ${ }^{15}$. Todo indica que con estas palabras se quería reconducir un proceso de división interna y de enfrentamiento de las partes que ponía en peligro la propia seguridad de la ciudad y amenazaba a su condición de villa de realengo. Ese partidismo necesariamente estaba alimentado por diferencias drásticas, tales como las que separaban a los ideales de los caballeros de la intención de mantener los fueros y un determinados status quo, que caracterizaba a los hombres buenos, unidas a otras razones de índole económica o social. En el caso de Talavera, parece que las divisiones se llegaban a plasmar en el propio espacio de la villa, y así el documento diferenciaba entre los que habitan en el castillo, los de la villa y los de los arrabales. A todos ellos les mandaba que se ayudasen mutuamente por bien de la villa, y que entre ellos hiciesen pleito homenaje, unos a otros. La carta fue leída en la villa y en los arrabales y ambas partes acordaron su contenido.

Vemos que esos acuerdos internos, en el seno de las villas, también se articulaban por medio de las relaciones feudales, aunque no tienen el sentido jerárquico que acostumbramos a dar al vasallaje feudal. Más parece que se trataba de una relación equiparada y en la que ninguna de las partes se situaría en la posición de señor, lo que aparentemente no impedía que se pudiese establecer pleito homenaje.

\footnotetext{
${ }^{84}$ Antonio Álvarez de MoRales, Las Hermandades, cit. , apéndice I p. 269. Hecha esta hermandad en Valladolid 14 de agosto de 1295, once días despues de la fecha en la que se constituyó la hermandad.

${ }^{85}$ Ibidem, apéndice III, p. 269.
} 
La hermandad de Cuenca se estableció entre los vecinos, estando reunidos en concejo, y allí se prometieron guardar amistad mutua y hacerse homenaje los unos a los otros, para defensa de la ciudad, servicio del rey y guarda del fuero, con las libertades y privilegios, que en él se contenían y con las mejoras que les hizo el rey Sancho IV $^{86}$. Se comprometían a ayudarse para mantener y hacer justicia, evitar que se cometiesen abusos y que se recaudasen impuestos o pechos en las aldeas de Cuenca, si no llevaban el consentimiento del rey o se hacían según el fuero. También disponían que se respetasen todos los derechos a los caballeros, que tuviesen casa en la ciudad y mantuviesen caballos y armas, al igual que a los que en el futuro viniesen a morar a la ciudad, para a continuación obligarse todos al cumplimiento de lo contenido en este documento de hermandad, bajo pena de traición y de pago de mil maravedíes, la mitad para el rey y la otra mitad para los que avalasen el privilegio. El traidor sería castigado con dureza, se le derribarían sus casas y se le consideraría como tal, tanto si actuase contra la hermandad como si no viniese en su ayuda, bajo pena de muerte sin caloña ninguna. De ese acuerdo se mandaron hacer tres copias que pasaron a manos de los linajes de Pero Fernández y de Juan Fernández, por una parte y del linaje de Gonzálo Rodríguez de otra, la tercera iría al pueblo de la villa ${ }^{87}$.

Cabe reconocer cierta relación entre la difícil situacion vivida en los años inmediatos a la muerte de Sancho IV y la aparición de esta nueva modalidad de hermandad que encontramos en los casos de Cuenca y Talavera, y que adquiere verdadero sentido en el contexto de su vida política interna, y de las luchas y conflictos allí desatados. El documento de Talavera no centra el asunto lo suficiente y por lo tanto cabe deducir que los conflictos podrían estar relacionados con la vieja rivalidad entre caballeros y hombres buenos, pero el de Cuenca es más explícito y menciona a dos linajes rivales, en los que se agruparían una buena parte de los caballeros de la villa, y a un tercer elemento que sería el pueblo ${ }^{88}$. En esa mención al

\footnotetext{
${ }^{86}$ Ibídem, apéndice IV, p. 270.

${ }^{87} \mathrm{El}$ origen de los linajes en Cuenca ha sido recientemente tratado por $\mathrm{M}^{\mathrm{a}}$ Concepción QUINTANILLA RASO, Política ciudadana y jerarquización del poder. Bandos y parcialidades en Cuenca, "En la España Medieval", 20 (1997), p. 224.

${ }^{88}$ Antonio Álvarez DE MORAles, Las Hermandades, cit., apéndice IV p. 271, "e por que esto sea firme mandamos al escribano facer tres cartas la una que tenga Juan Ferrandez, Pero Fernandez e su linage e la otra Gonzalo Ro/driguez e su linage e la otra el pueblo de la villa en que mandamos poner nuestro sello colgado".
} 
pueblo, no cabe suponer que se tratase tanto de la comunidad de la villa como de la vieja estructura del concilium, sobre la que se asentaba el poder de los hombres buenos. Las referencias a los privilegios del rey Sancho y a sus exenciones a favor de los caballeros, en tanto mantuvieran casa poblada, caballo y armas, dejan bien claros sus reivindicaciones, al tiempo que las peticiones relativas al control de la violencia y a la prohibición de poner pechos y otras contribuciones fiscales traducen el sentir de los sectores aferrados a la preservación de los usos y costumbres que lideraban mejor los hombres buenos.

La enorme actividad asociativa, desarrollada en este breve período de la minoría de Fernando IV, pone de manifiesto la eficacia y la difusión de las hermandades en la Corona de Castilla, y justifica una experiencia en los acuerdos interconcejiles que avalan las pretensiones de mayor protagonismo de las hermandades en el período siguiente.

\section{LAS HERMANDADES DURANTE EL REINADO DE FERNANDO IV Y SU PROLONGACIÓN EN LAS CORTES}

La vuelta de las hermandades a la escena política en 1295 se hizo bajo una apariencia de mayor rotundidad y con el propósito de no aceptar fácilmente una nueva disolución, tras la resolución de los conflictos del tránsito de reinado. Si bajo el reinado de Sancho IV la balanza política se había inclinado hacia los caballeros, en el de Fernando IV los hombres buenos tratarían de no perder posiciones y reclamar un mayor protagonismo. La minoridad del rey y las luchas de los tutores hacían cada vez más precaria la situación y las convocatorias de Cortes se convirtieron en frecuentes encuentros, de los que se servían los tutores y la reina para recaudar más y detallar algunas cuestiones de gobierno. Las convocatorias de Cortes se sucedieron de forma periódica, una o hasta dos veces al año, y en cierto modo pasaron a ser la caja de resonancia de los asuntos que preocupaban a la hermandad. No en vano a esas Cortes se llevaron algunos de los puntos defendidos por la hermandad y las propuestas de cargos recaían en su mayoría en los hombres buenos, mientras que sólo los 
asociados a la defensa se compartirían con los caballeros ${ }^{89}$. Aunque en los acuerdos de hermandad se mencionaba la presencia y asistencia a Cortes, es muy posible que en esos momentos no se pudiera todavía valorar el alcance que esta institución iba a tener para asegurar las bases del cumplimiento de los acuerdos.

En las Cortes de Valladolid (1295) se confirmaron todas las hermandades. En las de Cuéllar (1297) las hermandades impusieron que donde estuviese la corte del rey hubiese un consejo permanente, integrado por doce hombres buenos de los concejos. En las Cortes de Valladolid de 1298 se denunciaba la situación de desorden a consecuencia de las guerras y las malfetrias, que quebrantaban el orden. Allí se aprobaron duras medidas con castigos tales como la destrucción de sus castillos para los que cometiesen robos, y se encargó a los hombres buenos la realización de la pesquisa por malfetrías, también se denunciaron otros abusos sobre exigencias fiscales, practicados por ricos hombres, infanzones y caballe$\operatorname{ros}^{90}$.

La reunión de Cortes de Valladolid de 1299 tuvo un marcado objetivo fiscal para los concejos, que tuvieron que aprobar la concesión de tres servicios. Se dieron garantías sobre la justicia, al tiempo que se denunciaban nuevos abusos y malfetrías de los poderosos. Otro asunto de preocupación fueron las cartas desaforadas que se denunciaron en las Cortes de Valladolid de 1300. La difícil situación del reino se pulsó de nuevo en las Cortes de Zamora de 1301, en las que se mencionaban la sequía, el hambre y las malas cosechas y sus resoluciones se centraron en cuatro preocupaciones básicas: la fiscalidad, el abastecimiento, la justicia y el orden público ${ }^{91}$.

Las Cortes de Medina del Campo de 1302 fueron las primeras de la mayoría de edad y ya muestran el propósito del rey de contar más activamente con los hombres buenos, en particular para que vigilasen el espinoso asunto de las cartas desaforadas, que supuestamente emanaban en la

\footnotetext{
${ }^{89} \mathrm{La}$ relación y el estudio de las cortes del reinado de Fernando IV de incluye en el libro de César GonzÁlez Mínguez, Fernando IV, cit., pp. 29-258. Las de 1300 y 1308 en el trabajo de Joseph O'Callaghan, Las Cortes de Fernando IV: Cuadernos inéditos de Valladoid 1300 y Burgos 1308, "Historia. Instituciones. Documentos", 13 (1987), pp. 315-28.

${ }^{90}$ César GonzÁlez Mínguez, Fernando IV, cit., pp. 29, 45 y 54 respectivamente. Las Cortes de 1295 se encuentran en Angel BarRios, Jose María MonSAlvo y Gregorio del SER, Documentación medieval del archivo municipal de Ciudad Rodrigo, cit., doc 18, pp. 61-64.

${ }^{91}$ César González Mínguez, Fernando IV, cit., pp. 61-82 y Joseph O’Callaghan, Las Cortes de Fernando IV, cit., pp. 316.
} 
chancillería regia y ponían en cuestión el respeto a los fueros y privilegios de villas y ciudades ${ }^{92}$. A partir de esta fecha las convocatorias de Cortes se espaciaron en el tiempo y de los temas tratados destacan las peticiones hechas acerca de la justicia y de las anomalías de su cumplimiento. En 1307 aceptó el rey formar una corte de justicia presidida por el mismo, en la que los alcaldes serían caballeros y hombres buenos, adelantando algunas medidas que se ampliaron notablemente en las Cortes de Valladolid de 1312.

\section{A) Las Cortes de 1312}

La preocupación por la justicia y por las cuestiones de gobierno y orden público tuvieron en las Cortes de 1312 un destacado protagonismo ${ }^{93}$. Los apartados aprobados en estas Cortes esbozaban unos criterios básicos para su funcionamiento y también regulaban la actuación de los hombres de gobierno: adelantados y merinos preferentemente ${ }^{94}$. Se dispuso, en lo relativo a la administración de la justicia, que el tribunal del rey se reuniese los viernes y estuviese formado por alcaldes elegidos de entre los hombres buenos: cuatro de Castilla, cuatro de León y cuatro de Extremadura, que a su vez estarían asistidos de escribanos ${ }^{95}$. Se nombraban cuatro notarios con competencias, así uno sería del reino, otro de la Tierra, otro del reino de Toledo y el cuarto de Andalucía, cada uno asistido por tres escribanos. Un procurador del rey se ocuparía de la defensa de los más desasistidos, como eran las viudas pobres entre otros.

Lo interesante es que estas innovaciones se ofrecían en un clima de entendimiento con los hombres buenos y caballeros, y se asumía el compromiso de evitar la proliferación de cartas desforadas. En el propio acta de cortes, y como testimonio de buena voluntad que mostraba el propósito del monarca, se incluía la copia de una carta enviada al infante don Pedro y a otros miembros de la nobleza conminándoles a que pusieran fin a sus

\footnotetext{
${ }^{92}$ Ángel Barrios, Jose María MONSALvo y Gregorio del SER, Documentación medieval del archivo municipal de Ciudad Rodrigo, cit., doc. 24, p. 70.

${ }^{93}$ César González Mínguez, Fernando IV, cit., pp 173 y 239, opina que constituyeron un verdadero programa de gobierno.

${ }^{94}$ Rogelio PÉREZ-BuSTAMANTE, El gobierno y la administración territorial de Castilla (12301474), Madrid, UAM, 1976, I, p. 70 , considera que esas cortes tuvieron una gran importancia para el desarrollo de la administración.

${ }^{95}$ Cortes de León, cit., I, pp. 198-199.
} 
abusos y que no estorbasen a la justicia del rey, ni acogiesen a malhechores en sus dominios, que había sido dada en Palencia y a petición de este concejo el 23 de octubre de $1311^{96}$. A continuación se establecían criterios y principios que trataban de guiar la actuación de alcaldes, jueces y otros oficiales, conminándoles a cumplir con su obligación y señalando que se les pedirían responsabilidades ${ }^{97}$.

La mención permanente del derecho como salvaguarda de la integridad de las pérsonas y de sus bienes es una constante en este cuaderno de Cortes. También se reclamaba en él la independencia de los oficiales y se acotaba un territorio de cinco leguas en torno a la corte, dentro del cual se castigaría severamente cualquier delito cometido. Al final del mismo se incluían algunas modificaciones hechas sobre lo recientemente dispuesto, a tenor de las peticiones de los representantes de los concejos. Uno de los acuerdos se centró en restar dureza a esta disposición que acotaba el territorio de la corte, y curiosamente también se revocó la disposición que establecía que los escribanos levantasen acta de todo lo tratado en el concejo, dejándolo sólo para los actos de los que se pidiese fe por alguna razón. Esta negativa a establecer actas de los acuerdos del concejo justifica la ausencia de estos interesantes documentos hasta el siglo XV, en algunas villas y ciudades, a causa de la persistente oposición de los miembros de la oligarquía $^{98}$.

Estas Cortes de 1312 también fueron fundamentales para lograr restablecer unas garantías de justicia que fuesen mas allá de las etéreas promesas anteriores. En este sentido, parece evidente que la voluntad del rey era comprometerse en el desarrollo de un sistema judicial y de gobierno, tal y como le requerían las peticiones reiteradas de los procuradores de las ciudades, y hacerlo desde el respeto a los fueros y privilegios. La función regia se reduciría a ser el gestor de toda esa maquinaria de gobierno y a introducir leves cuñas de cambio a medida que las intervenciones por vía de apelación le fuesen ofreciendo oportunidades. Parece evidente que el derecho foral tenía vacíos difíciles de cubrir que a medio plazo exigirían nueva legislación y por ahí podría venir otra vía de cambio en el mundo del derecho, a favor de la unidad de acción y del poder regio, tal y como

\footnotetext{
${ }^{96}$ Ibídem, pp. 207-208, n 44.

${ }^{97}$ Ibidem, p. $209, \mathrm{n}^{\circ} 46$

${ }^{98}$ Ibidem, p. 214-219, n” 70-73-76-93 y 96.
} 
interesaba a la monarquía. Por lo tanto, la propuesta de las Cortes de 1312 no renunciaría aparentemente a los propósitos del poder monárquico y sí facilitaría la relación con las oligarquías urbanas a partir del respeto al derecho consuetudinario preservado en los fueros.

Es posible que no todas las ciudades se sintieran atraídas por esta vía que preservaba el derecho foral en el ejercicio de la justicia, y en este sentido parece sintomática la ausencia de alcaldes o escribanos procedentes de algunos concejos tales como Ávila o Segovia. La causa pudiera ser el mencionado predominio de los caballeros en ambos concejos, por lo que se sentirían menos atraídos por esa fórmula más favorable al predominio de los hombres buenos. Las innovaciones dispuestas en las Cortes de 1312 eran compatibles con el proyecto de construcción de un poder monárquico reforzado y comprometido con el respeto de los fueros, y su fracaso abrió las puertas a las formas centralizadoras del poder regio, logradas con la imposición del Ordenamiento de Alcalá de 1348.

A pesar de que el cumplimiento de esos acuerdos quedó interrumpido y sin seguimiento por la inmediata muerte del rey, sí cabe aceptar que estas Cortes fueron todo un programa de gobierno ${ }^{99}$ y que en ellas se veía la necesidad de que la monarquía participara más activamente en los asuntos relativos a la justicia y el gobierno de los concejos, objetivo a lograr desde la pluralidad de los fueros locales.

Se puede afirmar que, durante los diecisiete años del reinado de Fernando IV (1295-1312), las hermandades lograron alcanzar el tope en sus aspiraciones políticas y de intervención en los asuntos del reino. Se habían mantenido latentes durante su reinado, pero su programa de exigencias reaparecía puntualmente en las convocatorias de Cortes. Aunque las dificultades de la etapa de la minoría no permitieron un mayor control sobre las hermandades, tampoco tras la mayoría de edad el rey se atrevió a acabar con ellas. Incluso cabe admitir que éste monarca fuese un firme partidario de contar con los hombres buenos, junto a la nobleza y al clero, para regir el reino y que a ellos les encomendase la tutela y el control de las ciudades.

Una significativa disposición de las Cortes de 1312 reconoce a los hombres buenos y a los caballeros el beneficio de los privilegios de exención de pechos por los bienes que tuviesen fuera del lugar del que eran morado-

\footnotetext{
${ }^{99}$ César González Mínguez, Fernando IV, cit., pp 243-244. Este autor opina que en ellas trató de dar un nuevo rumbo a la política y cedió ampliamente a las pretensiones de los concejos.
} 
res, salvo a los de Castilla que debían pagar la martiniega. Esa equiparación resulta significativa en tanto suponía abrir el rápido acceso a la nobleza por la vía de la exención, que se ampliaba a bienes situados fuera del marco local. Ese giro notable de apoyo a los hombres buenos y caballeros prueba el deseo de la monarquía de asentarlos económicamente, en tanto que sector social capaz de dar estabilidad en un momento difícil, en el que la amenaza de los malhechores se sumaba a otras injusticias del período ${ }^{100}$.

La situación de los hombres buenos se habría ido modificando en el curso de los siglos XI al XIII, y eso a pesar de la aparente unidad mostrada por ellos tras los iniciales episodios de las hermandades. Estos que eran representantes de un grupo privilegiado, se identificaban en villas y ciudades con las jerarquías naturales que gobernaban el concejo, pero desde 1282 habrían visto lastradas sus posiciones políticas y mermado su prestigio social frente al imparable ascenso de los caballeros que bien organizados acaparaban riquezas y poder. El apoyo popular conseguido para evitar la desaparición de los fueros, y frenar abusos y violencia contra personas y haciendas, se fue transformando por razones estructurales y también de coyuntura. No olvidemos que la tendencia disgregadora en aquella sociedad haría perder prestigio y fuerza a los hombres buenos, en particular cuando medían sus fuerzas con los caballeros, mejor preparados para su afianzamiento en la sociedad feudal, hábilmente organizados en linajes de construcción horizontal en los que se agrupaban, y capaces de desplegar una enorme fuerza, tal y como se pudo probar en algunas de las luchas de bandos acaecidas en este período.

Los años de colaboración activa con la monarquía y más tarde con la nobleza, también les pudieron acarrear episodios de desgaste que se percibirían de un modo general en la ineficacia de su gestión. La prueba más palpable eran las reiteradas peticiones de Cortes que planteaban siempre los mismos ruegos, lo que venía a mostrar que nunca se ponían remedios eficaces a sus demandas. Por otra parte no hay que olvidar que la tendencia individual de estos hombres buenos era medrar para conseguir sus metas propias, tales como mejores rentas o el ennoblecimiento de su linaje familiar, al lograr el tratamiento de hidalgo o infanzón. Las afinidades que ellos

\footnotetext{
${ }^{100}$ Cortes de León, cit., I, pp. 217-218, 90, "Otrosi alo que me pidieron quelos caualleros e los omes buenos de Castiella e de Leon que non paguen pecho ninguno ssino alli donde son moradores por algo que ayan en otro lugar: otorgolés esta petiçion salvo en Castilla la martiniega".
} 
sentían con la nobleza por razones del origen de su poder y prestigio, les hacían fácilmente asimilables a esta clase social en diferentes aspectos.

Todos estas circunstancias contribuirían a desdibujar la imagen que los hombres buenos hubieran exhibido de sí mismos y de su causa desde el inicio del movimiento de las hermandades, posiblemente porque a partir de 1312 perderían el liderazgo en los acuerdos de hermandad que se harían con la nobleza y donde ya figuraban los caballeros. Sin olvidar que las convocatorias de hermandades, pactadas con la alta nobleza después de 1312, seguían poniendo el énfasis en los mismos viejos asuntos.

\section{LA HERMANDAD DE 1312 A 1325 . LA NOBLEZA}

La muerte del rey en 1312 volvió a dejar el reino en una situación crítica debido a las amenazas exteriores y a los conflictos internos. Se planteaba una nueva etapa de minoría, al frente de la cual se situaban doña María de Molina y dos grandes nobles: el infante don Juan, hermano de Sancho IV y el infante don Pedro hermano del fallecido rey. Desde 1312 algunos concejos hicieron cartas de hermandad que parecen más acuerdos locales que otra cosa. El deteriorado documento de Ledesma recoge el acuerdo de la hermandad de León y sus resoluciones se centraban en dos aspectos básicos: la defensa del rey y el mantenimiento de ciertas garantías para asegurar la acción de la justicia sobre los autores de malfetrías ${ }^{101}$. Es posible que la violencia en el seno de los concejos, asociada a los conflictos por el uso y propiedad de la tierra, el control sobre bienes y personas y la movilidad de animales y personas en el territorio de los concejos, resumirían las razones de conflicto, en los que se verían involucrados de un modo $\mathrm{u}$ otro los vecinos de los concejos de villas y ciudades. Eso justificaría la vuelta a los asuntos inmediatos y el alejamiento de las altas propuestas políticas.

En febrero de 1313 el infante don Juan consigue atraerse a las hermandades y hace un acuerdo con las mismas que quiere ser un programa de propuestas casi equivalente a un cuaderno de Cortes. Gracias a esos compromisos acordados, el infante don Juan consigue para su causa a los

\footnotetext{
${ }^{101}$ Alberto MARTín ExPÓsito y Jose Ma Monsalvo ANTÓN, Documentación medieval del archivo municipal de Ledesma, Salamanca, 1986, doc. 10, pp. 48-49. La adhesión de Ledesma al acuerdo se expresa en el documento de 11 de diciembre de 1312, p. 50.
} 
concejos, organizados en hermandades ${ }^{102}$. Esa intervención de la nobleza también se produjo en la constitución de la hermandad general de Andalucía de 1313, si bien en este caso su presencia parece justificada por la prioridad que tenía la defensa de la frontera ${ }^{103}$.

Este acercamiento entre nobleza y hermandades no puede ser entendido como una asociación contra natura que desvirtuaba el sentido de la hermandad al haber perdido las carácterísticas de independencia del primer período ${ }^{104}$. Tal y como vimos en el seguimiento acerca del desarrollo de las hermandades, la nobleza jugó un papel importante y se la puede considerar inspiradora de las mismas, ya que animaron algunos de los episodios de 1282, y pactaron con algunos concejos, como vimos en los casos de Segovia y Andalucía, al tiempo que en general se producía esa buena sintonía entre nobleza y hombres buenos por la defensa del reino, de los fueros, del orden y de otras muchas propuestas. Mayor oposición y rechazo manifestaban los miembros de las hermandades hacia los caballeros, enemigos locales en algunos casos y protagonistas de episodios de violencia en la línea de los practicados por los malhechores feudales, y ello sin que se pueda entender esa diferencia como un conflicto radical, equiparado a la lucha de clases, ya que era evidente que ambos formaban parte del grupo oligárquico con similares intereses, y que hombres buenos y caballeros también compartían otras preocupaciones de ámbito local, tales como la defensa del concejo y la preservación de sus hombres y sus riquezas.

Con la desaparición de los tutores en la derrota de Elvira el 24 de junio de 1319 frente al ejército del emir de Granada, la situación se prolongaría con nuevos protagonistas que pugnaban por la tutoría del rey y que utilizaban a los concejos, organizados en hermandades para su propósito. Esa dinámica empobrecía ciertamente la capacidad de acción de los concejos hermanados y a medio plazo acabaría con la unidad, pero no es esa la causa de su desaparición en 1325, cuando el rey Alfonso XI las suprimió en las Cortes de Valladolid.

\footnotetext{
${ }^{102}$ Juan Ignacio RuIz DE LA PEÑa, La Hermandad Leonesa de 1313, "León Medieval. Doce Estudios" (1978). pp. 150-151.

${ }^{103}$ Manuel García FERnÁNDEz La Hermandad General de Andalucía durante la minoría de Alfonso XI.., cit., pp. 366-695.

${ }^{104}$ Luis SUÁREZ FERNÁNDEZ, Evolución histórica de las hermandades, cit. p. 25.
} 


\section{EL FIN DE LAS HERMANDADES. INSTITUCIONES Y SÍMBOLOS DE LA HERMANDAD}

Sin querer entrar en una valoración profunda de los mecanismos y razones que abocaron a este fin de las hermandades, sí cabe admitir que la suerte de las mismas parecía echada desde el momento en el que el programa dispuesto por Fernando IV en 1312 quedó postergado. Esa propuesta de organización de la administración de justicia y de actuación de adelantados y merinos, junto a otros oficiales, en todo el reino era la garantía del mantenimiento de los fueros particulares y de su aplicación. El desarrollo de un sistema judicial y el establecimiento de unas vías de apelación hubiera reinstalado la justicia sobre el respeto al derecho consuetudinario, acabando con violencias y conflictos internos, al tiempo que se hubiera abierto la posibilidad de un seguimiento conjunto en los asuntos tratados. Fernando IV creyó en el papel de las hermandades y contó con ellas hasta el final de su reinado, atendiendo sus demandas y súplicas. Tras su muerte nadie se volvió a acordar de lo dispuesto en aquellas Cortes de Valladolid y se prestó más atención a contener los efectos de la crisis de sucesión, que en este caso serían los derivados de la violencia de los malhechores feudales, postergando el tratamiento de la causa, que era la eficacia y el buen funcionamiento de la justicia.

El fin de la hermandad se dispuso en las Cortes de Valladolid de 1325, cuando de forma sutil el rey confirmaba todos los privilegios y cuadernos que su padre dio a los concejos excepto los que hablasen de hermandades y de igual modo lo planteó en las Cortes de Madrid $1329^{105}$. La escasa reacción a la prohibición denota que las hermandades habían perdido sentido desde 1312 hasta 1325 y la decisión de Alfonso XI sólo vino a dejar bien sentado que no admitiría de los consejos nuevas formas de asociación con ambiciones políticas. Además este monarca inició una política de progresivo acercamiento a los caballeros de las ciudades del reino, que le sería muy provechosa para los importantes cambios que pensaba introducir en su reinado.

\footnotetext{
${ }^{105}$ Cortes de León, cit., I, p. 388, n" 40: "Otrosi les otorgo los quadernos queles dio el Rey don Ffernando mio padre en las cortes que el fizo, aquellos que non fablan de hermandades". Con las mismas palabras en las de Madrid de 1329, pp 433-434.
} 


\section{CONCLUSIÓN}

Las ciudades y villas del reino, gobernadas por concejos de hombres buenos se lanzaban a la defensa de los fueros en 1282, este había sido el punto de partida y también la razón de existencia de las hermandades, su fracaso vino sellado por la incapacidad para conservarlos. Tampoco fueron eficaces para mantener el orden en el seno de sus villas y territorios, lo cual mermaba su eficacia y credibilidad. Es preciso reconocer que en su contra tenían como lastre la división interna que protagonizaron los caballeros, la carencia de apoyo militar para la defensa de su territorio y sus argumentos, y el primitivo sistema de financiación que mermaba los medios económicos.

La monarquía por su parte adoptó un papel ambiguo, si bien con Fernando IV el objetivo del poder monárquico parecía compatible con la preservación de usos y costumbres y el apoyo al sector oligárquico de los hombres buenos y caballeros capaces de mantenerse en una posición jerarquizada en el seno de sus ciudades y de colaborar con la monarquía en las acciones de gobierno y fiscalidad. Pero la opción de apoyo a los caballeros, en la línea de lo dispuesto por Alfonso X en 1264, seguía resultando atractiva, habida cuenta de su condición militar y del favor que podían prestar a la continuación de la Reconquista. Además los caballeros asumían con facilidad los principios feudales de organización del poder y la sociedad y podrían convertirse en aliados eficaces.

$\mathrm{Al}$ margen de los toques que la intervención de la nobleza introdujo, el episodio de las hermandades constituye la experiencia política más interesante de la plena edad media, que marcó el inicio de una nueva era en los planteamientos de participación política de los concejos y les ayudó a adquirir conciencia de su propia naturaleza y fuerza política, y de su razón de ser en el conjunto del reino. La dotación de determinados símbolos a las hermandades prueba el deseo de reconocerlas como instituciones con entidad y voluntad de perdurar. Sin olvidar que algunos de esos símbolos elegidos coincidían en ser emblemas de la monarquía o del reino como la figura emblemática del apóstol Santiago. Esa experiencia en la que se unía la fraternidad y el deseo de participar en los asuntos del reino, codo a codo con los grandes nobles y eclesiásticos, representa la enorme capacidad de acción de este movimiento concejil desarrollado a lo largo del siglo XIII. 


\section{RÉSUMÉ}

Dans les villes castillanes du XIII ème siècle avait deux groupes qui partageaient le pouvoir: les hombres buenos qui étaint les hiérarchies des groupes familières, et les caballeros-villanos (chevaliers). Leur rivalité est devenue plus forte pendant ce siècle, quand le roi Alphonse $\mathrm{X}$ favorisa les chevaliers et introduisit des nouveaux codes législatifs qui voulaient substituer le droit coutumier (fueros). En 1282, les hombres buenos s'organisaient avec la noblesse en forment les hermandades, associations pour intervenir dans la politique du royaume. Pendant ces années et jusqu'à 1325 on essaye la possibilité d'une nouvelle forme de monarchie féodale à la Couronne de Castille, organisée sur la collaboration des hiérarchies locales, associées en hermandades et ayant représentation en Cortes, assemblée représentative, aussi sur le respect au droit coutumier des fueros. L'échec essuyée par l'hermandad arriva depuis 1312 et ouvrit les portes au chevaliers-villanos, le groupe social qui était tout prêt à collaborer avec la monarchie et son projet interventionniste et autoritaire pour les villes castillanes. Quand le roi Alphonse XI supprime les hermandades en 1325, elles étaient si désarticulées que aucune se résistée.

\section{SUMMARY}

The rivalry between the two most relevant social groups was increased in the Castilian towns during the XIII century, when the king Alphonso the Wise (1252-1284) felt in favour with the caballeros villanos and introduced new rules and laws that banished the ancient customary laws (fueros). In 1282 the hombres buenos and the nobility were organised in brotherhoods, called hermandades. They had an active role in the politic decisions. Until 1325 they try the possibility of a new kind of feudal monarchy in Castile based in a relevant influence of local hierarchies, organised in hermandades, with a representation in the Cortes (Parliament) and the use of customary laws. The fall of the hermandad happened about 1312 . This fact opened to the caballeros villanos a new way to collaborate with the monarchy and his wide interventionism and authoritarian politic in the towns. When in 1325 Alphoso XI finished with the hermandades, it had been disjointed and he didn't find a scarce resistance. 